\title{
EXTERNALITY AND INCORPORATION IN THE WORLD-SYSTEM: ABYSSINIA - ANOMALY OR PALIMPSEST?
}

\author{
Jon D. Carlson \\ School of Social Sciences, Humanities \& Arts \\ University of California \\ Jcarlson3@ucmerced.edu
}

\begin{abstract}
This article examines the concept of the 'external arena' and the role of the 'information network' in the expansion of the world-system and incorporation of new regions. To address systemic incorporation, I reference research on nested networks of interaction, and echo criticisms that the impact of myth and misinformation has been underappreciated as an element of incorporation. Significant alteration occurs well-prior to the point at which most worldsystems literature considers a region incorporated. I offer the concept of "protoglobalization" as a means of conceptualizing this early, overlooked social, economic, and political change. Abyssinia is of interest because it offers a rare case of cross-systemic incorporation. The region was historically part of the Red Sea trade complex, had linkages throughout the interior of Africa, and existed on the periphery of the Indian Ocean world-system. So while initially outside the realm of European contact, this case offers an example of successful resistance to incorporation and how that process can be understood. Additionally, it offers a case study of cross-systemic incorporation, which has been lacking in the literature. As such, it also contributes to the concept of a 'contested periphery'. The case reaffirms the significant impact external regions can have on the functioning of "internal" system actors; the mere myth of Prester John spurred significant effort by European powers to locate his legendary Christian Kingdom. Finally, the article uses the methodological innovation of historical maps to trace the border of the 'information network', which allows for a refinement of our understanding of the complex process of incorporation and an improved model of the relationship between networks of interaction, frontiers, contestation, and incorporation.
\end{abstract}

\section{INTRODUCTION}

To expand upon existing research on 'incorporation' into the world-system, I undertake a specific case study of a region external to the expanding European world-system. Accordingly, this is meant to flesh-out the middle ground between Wallerstein's $(1974,1980,1989)$ analysis of incorporation (European-focused, state-centric, 'inside-out') and Hall's (1986, 1987, 1989) research on frontiers and incorporation (external, indigenous-oriented, 'outside-in'). This case also supports the 'pulsation' thesis of world-systems (Hall 1987, 1989, 2005; Chase-Dunn and Hall 1997; Beaujard and Fee 2005), offering insight for future cross-systemic study: are zones along system borders repeatedly incorporated as they fall in and out of neighboring systems, or are they mere geographic socio-cultural bridges between systems? Accordingly, the case of 
Abyssinia is also applicable to research on 'contested peripheries' (Allen 1992, 1997, 2005; Cline 2000; Hall 2005). Such areas have "geographical, political and economic implications, since the affected region lies between two larger empires, kingdoms or polities established to either side of it" (Cline 2000: 7). Furthermore, the Abyssinian case offers insight into the ability of regions to maintain externality, or 'negotiate peripherality' (Kardulias 1999, 2007). Ethiopia (née Abyssinia) maintained independence from colonial subjugation well into the twentieth century, despite being linked to the African, Eurasian and Indian Ocean systems (Beaujard and Fee 2005; Beaujard 2007). Finally, because of the long historical overview of this case, it also lends support to the application of world-system analysis to pre-capitalist settings, as has been argued by AbuLughod (1989, 1993), Chase Dunn and Hall (1991), Frank (1990, 1998), Frank and Gills (2005), Gills and Frank (1991), and it echoes concerns with globalization as having a considerable historical legacy ( $c f$., Gills and Thompson 2006). The interaction between systems is also a useful homologue for contemporary discussions about cultural globalization and civilizational 'clashes' (Huntington 1993). Thus, I use a 'palimpsest' ${ }^{1}$ as a fitting image for the examination of Abyssinia, sitting at the nexus of the African, Indian Ocean/Red Sea and European worldsystems.

I use Chase-Dunn and Hall's (1991, 1997) and Hall's (1986, 1989, 1999a, 1999b, 2009) notion of nested networks of interaction combined with Carlson's (2001, 2002) 'zone of ignorance'. By treating networks as various 'states of being' through which a region passes and is briefly temporally fixed, one can operationalize incorporation more specifically. So a region can be in 1) a 'zone of ignorance' (ZOI) - where next to nothing is known and myth carries as much weight as fact and beyond which an area exists which is 'external'; 2) the 'information network' (IN) - of regularized information exchange and cultural interaction; 3) the 'prestige goods network' (PGN) - of regularized luxury and high value-to-weight goods exchange; 4) the political-military network (PMN) - of regularized military and/or political interactions; 5) a bulk goods network (BGN) - a system of regularized exchange of low value to weight goods. Accordingly, this case study adds to the "variance-maximizing" strategy that Hall (2009:29) calls for regarding the study of frontiers, and which applies to studying cases of incorporation.

The case study focuses on the transition from the zone of ignorance, to information network, to prestige goods network, ending with the political-military network. As historical maps are reflections of a given information network, a 'freeze-frame snapshot' of accumulated knowledge, these are used to parse the status of a given region at a particular historic moment. Maps in conjunction with other written sources are used to give a clearer picture of a given region during the period of incorporation ( $c f$., Carlson 2001:253-254), especially the transition from zone of ignorance to information network, as maps often capture the myths, rumors, and biases (geographic and otherwise) of a given historical period or worldview.

The academic discussion of Abyssinia, or what is largely modern Ethiopia, is often cast in terms of the country's unique status within the African continent. It was the only African polity to survive intact into the twentieth century and is remarkable in its very antiquity. Ethiopia is studied precisely because of this dual aberration. But this perception of Abyssinia as unique has created a certain amount of intellectual blindness to its role in the social systems of North

\footnotetext{
${ }^{1}$ A 'palimpsest' is a page from a scroll or book, often of parchment, that has been scraped clean and reused. Over time the faint remains of the former writing could reappear enough so that scholars could discern the text (scriptio inferior, the "underwriting") enough to be able to decipher it.
} 
Africa, the Arab peninsula, the Red Sea and the Indian Ocean. This blindness manifests in the treatment of Ethiopia as isolated or insurmountable and has resulted in an ability to explain anything Ethiopian by geography. This "geographical determinism" produced an "isolation paradigm" that predominates in Ethiopian studies (Tibebu 1996), resulting in a dominant view of Ethiopia as an anomaly or paradox within the field of African studies (Jesman 1963). The "anomaly and paradox" thesis has resulted in Ethiopianist studies being treated as an outgrowth of Orientalism: "Ethiopians are Semitic, not Negroid; civilized, not barbaric; beautiful, not ugly; ... all are images of Orientalist Semiticism in the Western paradigm of knowledge" (Tibebu 1996:427; cf., Marcus 1971). Even noted Africanist Ali Mazrui places emphasis on the triple heritage of Ethiopia - Indigenous, Semitic, and Greco-Roman - as distinct from the larger heritage of Africa as embodied in the triple modern personality of Nigeria (Mazrui 1984:13).

The "isolation paradigm" ascribed to Ethiopia overlooks the overt linkages the region had to the outside world. More relevantly, it allows a false construction of Ethiopian history, such that "Ethiopia has been perceived as outlandish to the general African scene. Ethiopia is supposedly located in the wrong place. Ethiopia is in Africa but not of Africa" (Tibebu 1996:428, emphasis in original). Why is this crucial? On one hand, it reifies the Eurocentric approach to much of African pre-colonial, colonial, and post-colonial history and development which is itself inherently Eurocentric in that African history is defined in a context of European colonialism. Yet more insidiously, it allows the removal of the one example of "African success" from any discussion of African political development. No longer do we have the example of an African polity surviving into the twentieth century as a functioning part of 'international society'. Instead, Ethiopia is an 'anomalous paradox'. This allows scholars to ignore what was required to subjugate the rest of Africa, to neglect the question of why the rest of Africa became colonized and exploited by European interests. Rather, if Abyssinia/Ethiopia is considered "African" the question becomes, "If possible in Ethiopia, why was success not possible elsewhere in Africa?' Or asking the historical counterfactual, 'Does Ethiopia provide an example of what was possible in Africa if the colonial interlude had happened differently?'

By the turn of the twentieth century, Abyssinia was an independent African island surrounded by a sea of European colonial aspiration. To make this point - as well as to provide a frame of reference for the historical discussion of Abyssinia - that one can appreciate Figure 1, the map of "Abyssinia and Surrounding Countries". From 1904, the map reaffirms Abyssinia as a recognized independent polity amidst the colonies of Britain, France, and Italy. British Egyptian Sudan and British East Africa dominate the region to Abyssinia's west and south, and these holdings are balanced by British Somali Land to the east. Italy abuts Abyssinia to the north and southeast with Eritrea (an Italian colony) and Italian Somali Land respectively. French Somali Land completes the European colonial encirclement. Notably, Eritrea occupies much of what had been historically subject to the empires of Abyssinia, based significantly on the Red Sea trade network. For example, Axum is on the far northern frontier of Abyssinia in the 1904 map, yet much Axumite trade came via Adulis on the Zula inlet of the Red Sea. Other historically

2 This is most obviously indicated in that Ethiopia was a member of the League of Nations, joining in September of 1923. But Ethiopia was diplomatically active in the international community even earlier, being a signatory member for the creation of an International Institute of Agriculture and later even entering into trade agreements with the United States, for example (see "Convention...", 1908; "Treaty...", 1914). 
important features include Lake Tana - which appears on earlier maps as a possible source of the Nile, and Gondar just to the north of the lake. This encroachment on Abyssinia's borders eventually leads to conflict with the colonial powers.

Figure 1: Rand McNally (1904). "Abyssinia and Surrounding Countries", from Atlas of the World. New York: Rand McNally \& Co., pp. 151, author's collection.

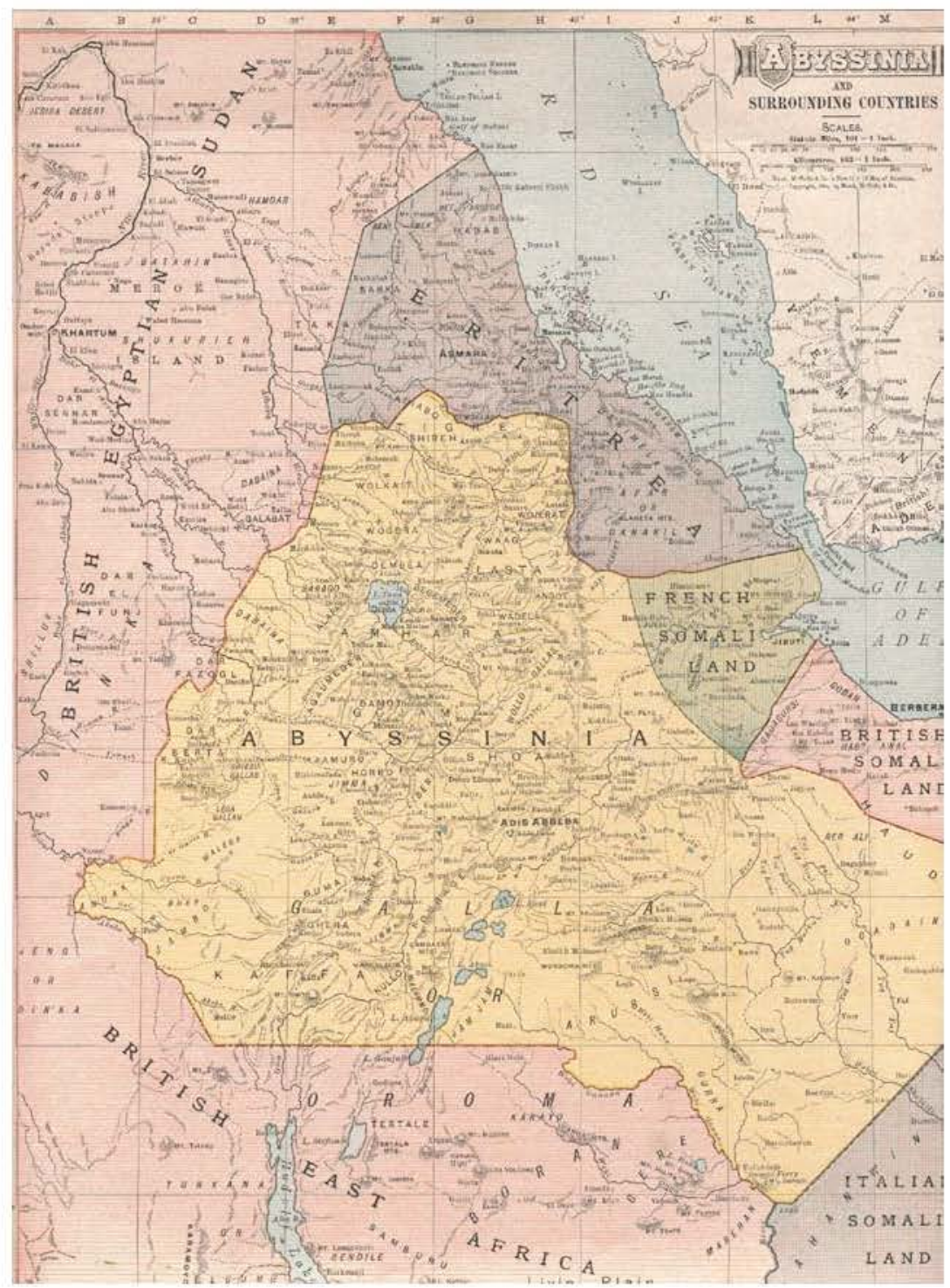

Even by 1904, there remained minor uncertainty regarding Abyssinia's geography. For instance, some of the rivers are only tenuously drawn as they transit between solid sections that had been already mapped (e.g., the Blue Nile). More than fifty years later, even simple geographic relationships taken for granted elsewhere in the modem world were still a point of 
debate with regard to Ethiopia: did snow exist in Ethiopia's mountains and did this contribute to Nile flooding? (e.g., Simoons 1960). The conclusion reached was a qualified "yes" regarding the snow, and "no" regarding the flooding. Much of the European world's awareness about Ethiopia and its history was similarly late in coming and subject to qualification. Ethiopia's very existence as a functioning, independent state was subject to ongoing modification and negotiation. Indeed, Ethiopia's status as an independent state appeared as tenuous as the debate over the existence of the mountain snows. Much like the tradition of snow in the Ethiopian highlands, the history of the Ethiopian state in European context is a debate over something that has been there all along.

\section{ABYSSINIA IN A WORLD-SYSTEMS CONTEXT}

It is to get at a better understanding of Ethiopian history that Tibebu (1996:428) argues a "political-economy approach to Ethiopian history, within the larger cosmos of African history, can be an alternative paradigm for the study of Ethiopian history." While this reframes Ethiopian history in a larger perspective, it also contributes to the dialogue of African development. If the isolationist paradigm of Ethiopia lacks support, what does this have to say about other instances of African political development and colonial contestation? To what extent was the region linked to the political, economic and social developments of the surrounding region? How relevant is this for the understanding of the emergence of the world-system and the process of incorporation? In turn, this has implications for the understanding of state development in Africa and other nonEuropean regions, the emergence of the state system as a whole, and the gradual expansion of 'international society' ( $c f$. ., Bull 1984).

Instead of approaching Abyssinia as an anomaly or paradox, a world-systems approach allows us to study the history and evolution of Abyssinia as a palimpsest. Quite literally, instead of a text of Ethiopian history as isolated and removed from the surrounding region, this emphasizes the interactive, constantly revisited nature of socio-political evolution; the text of history is always in the process of being partially erased and overwritten. This allows for the exploration of recurring themes in Ethiopian history: 1) the relationship to the Arab world and the Arabic slave-trade, 2) the institution of Christianity and rule by Coptic Egyptians, 3) the creation of a European 'myth' of Prester John, 4) the benign isolation afforded by the high plateau of Abyssinia, 5) the emergence of an agricultural society, 6) the relationship with the Red Sea trade, and 7) the evolution of Ethiopian interaction with Europe.

\section{Abyssinia in Antiquity}

Contrary to the paradigm of isolation, the history of Abyssinia is a long and interactive affair. As Diamond (1997) reminds us, humans as a species came 'out of Africa', and the Great Leap Forward for human societal development dates to around 50,000 years ago, when the first signs of standardized stone implements and preserved jewelry ${ }^{3}$ are found in East African sites

\footnotetext{
${ }^{3}$ Diamond identifies the jewelry as ostrich-shell beads. Elsewhere, jewelry or ornamentation is also part of the story when discussing trade networks or patterns of exchange, especially among "primitive" cultures and prestige goods ( $c f$. . Bennyhoff and Hughes 1987, Karklins 1980). This raises a potential avenue of specific research for examining the timing and extent of down-the-line trade and growth of prestige goods
} 
(1997:39). The earliest hominids, Australopithecus -- including the well-known 'Lucy"-- were found in the Rift Valley in eastern Africa and are dated between 5.8 and 3.0 million years ago (Phillipson 2005:32-3). And the earliest stone tools (2.6 mya) have been found at the site of Gona in Ethiopia. So there is a certain amount of irony involved in any discussion of the cradle of human evolution being "effectively linked" to the expanding European world-system.

While it is not required to trace the development of Abyssinia through 50,000 years of history, it is relevant that the region was one of the first to develop organized agriculture. Indigenous grasses such as teff and finger millet were later complemented with a package of crops from the Fertile Crescent: wheat, barley, peas, and lentils. Ehret (1979) observes that Ethiopian agriculture traces its roots to the intensive utililization of the indigenous wild grains as early as $13,000 \mathrm{BCE}$, with more formalized grain cultivation emerging at least 7,000 years ago. While there may be debate over whether agricultural cultivation originated in Ethiopia or was a spillover from the Fertile Crescent, it was well established by approximately 5,000 BCE. While most of the indigenous Ethiopian plant species are still largely confined to the region, at least one (the coffee bean) has become a sought-after bulk good in the modern world economy and contributed to Ethiopia's position in the Red Sea and Mediterranean trade ( $c f$. ., Aregay 1988).

Why emphasize agricultural production? Because agriculture is the foundation on which state development stands. Organized agriculture provides for the extraction of surplus to allow specialization, and is a crucial determinant of bulk-goods linkages throughout a given system. In Ethiopia, as elsewhere, central administration based on agricultural production surplus also produced writing, an organized ruling class, and the creation of a formal military structure. The Ethiopian alphabet is based on a modified Arabian alphabet, in turn evolved from the earliest Semitic alphabets (Diamond 1997:227,400). Elsewhere in sub-Saharan Africa, the alphabet was much later in coming and was introduced by Arab or European traders. Further, iron use is present early in Abyssinia, where lacking elsewhere in Africa (Wainwright 1942). With agriculture as the basis for the emergence a modern state, inclusive of a literate society, Ethiopia developed into a functioning state well prior to European expansion.

In fact, the region underwent a succession of empires and states, largely because it was part of the Red Sea and Middle Eastern trading system. Pankhurst (1997) points out that the historical kingdom of Punt is associated with Ethiopia, with the first known Egyptian records of contact with Punt dating to around 3,000 BCE. Later, the kingdom of Da'amat (also D'mt) was located in the highlands of western Tigre and held a peripheral role in the region: "It exchanged ivory, tortoiseshell, rhinoceros horn, gold, silver and slaves for such finished goods as cloth, tools, metals, and jewelry" (Marcus 1994:3-4). While most modern historians consider Da'amat indigenous ( $c f$., Munro-Hay 1991:57), some argue that it was an admixture of indigenous peoples and a "culturally superior" Sabaean expansion from the Arabian peninsula (cf., Tamrat 1972). Regardless of the debate surrounding the origins of Da'amat and the degree of Sabaean influence, the kingdom collapsed by about $100 \mathrm{BCE}$ when rivals managed to divert trade to cities with easier access to the Red Sea, though the region continued to be heavily influenced by patterns of regional trade.

networks: jewelry and ornamentation. By definition not a necessity, is jewelry a 'canary in the coalmine' of cultural exchange, since local or traditional types of ornamentation are most easily replaced with exotic 'foreign' material? The opposite flow of ornamental material is also interesting, as exotic items of limited local value were occasionally in high demand within "civilized" society (e.g., pearls). 
Another early major trading state explicitly associated with Ethiopia was Axum, which rose to prominence around $100 \mathrm{CE}$, linked to the stimulus provided by Ptolemaic Egypt and later by the Roman world-economy (Marcus 1994). Centered on the city of Axum, it encompassed the important costal port of Adulis (also Adulé), and several ports further east on the Aden coast. Exports included ivory, rhinoceros horn, tortoise shell and obsidian, ${ }^{4}$ with "hippopotamus hides, apes and slaves" as noted by Pliny. Imported goods - originating predominantly from Egypt, India and Arabia - were more varied, and included cloth from all three regions, varieties of glass, sheets of copper for making utensils, iron for weapons and tools, finished axes, adzes and swords, wine, limited amounts of olive oil, and some money (cf., Marcus 1994:5-7, Pankhurst 1997:18$20)$.

The importation of money indicates a level of commerce requiring an easier method of exchange, though it was, at first, only "for foreigners in the area" (Pankhurst 1997:19). By late in the third century, however, Axum was minting its own coins. This is relevant for two reasons. First, "the mere existence of Axumite money signaled Ethiopia's major role in the Middle East, where only Persia, Kushanas in India, and Rome circulated specie" (Marcus 1994:7). The second reason the Axumite specie is important is reflected in its use, illustrating Axum's position in the regional economy. As a "proto-global" currency, the first Axumite mintings were in Greek with denominations based on fractions of the Roman solidus, indicating that the coinage was used primarily for international trade. In contrast, the majority of the Axumite population - and domestic commercial relations with the interior - continued to use bars of iron and salt as primitive currency. The bars of rock salt provided an important link to the gold trade to the west and southwest of Axum (Marcus 1994:6-7, Pankhurst 1997:25).

The coins of Axum capture another important aspect of the kingdom - the adoption of Christianity during the third and fourth centuries CE. This is arguably the most important incorporative event for the region. It provides the basis for the myth of Prester John, which fires European imaginations. The Axumite decision to adopt Christianity reflects trade-related issues of the time:

At court, the ideology was discussed philosophically but also, as befitted a place of power, in economic and political terms. Context was paramount: by the early fourth century, Christianity had become the established religion of the eastern Roman Empire. Since Roman trade dominated the Red Sea, it was inevitable that Christianity would penetrate Axum (Marcus 1994:7).

Conversion to Christianity occurred slowly and was initially limited to trade routes and towns. It eventually gained broad acceptance, as embodied in the conversion of the Axumite King, Ezana. The coins issued during Ezana's reign (ca. 321-360) initially carried his picture with a representation of the sun and moon, but after his conversion to Christianity Axumite coins were embossed with the Cross of Christ - "the first such emblem to appear on a coin anywhere in the world" (Pankhurst 1997:23). The currency of Axumite trade and empire became a reflection of the ideology carried to Axum as part of the Roman Red Sea trade package.

\footnotetext{
${ }^{4}$ The obsidian was used to manufacture jewelry and offerings, and likely came from a coastal area east of Adulis.
} 
Axum's power waned from the late 500 s through $1000 \mathrm{CE}$, as Persia emerged as a regional power in the late sixth century. With the growth of Muslim power and influence in the eighth century, Axumite shipping in the Red Sea-Indian Ocean trade soon fell into decline. No longer the center of the Red Sea trade, the coastal region lost its economic vitality and trading centers withered. The kingdom was overthrown by the twelfth century, and the center of power shifted southward to the new capital at Roha, now Lalibela (after Emperor Lalibela who ruled ca. 1185-1225) (Marcus 1994:10-12, Horvath 1969:206).

The reign of Lalibela is most commonly associated with the Prester John myth. Rumor of a Christian kingdom beyond the realm of Islam had circulated for centuries, and it is fairly certain that these rumors were based on the factual existence of Axum. By 1165, these rumors gained credence in the form of a letter allegedly sent by the ruler of a distant Christian kingdom that circulated throughout Europe. This letter and numerous subsequent variations of it, while a "wondrous concoction", is the basis for the legend's spread in Europe and describes the Prester as, 'ruling in 'India,' a geographical expression that to Europeans in 1165 and much later meant nothing more specific than a land lying to the east" (Nowell 1953:435). Nevertheless, it also served as impetus for the eastward journey of Marco Polo from 1271-1295. ${ }^{5}$ Upon Polo's return and distribution of his writings, the myth of Prester John became a geographical problem.

Why does Marco Polo's journey present a problem for the Prester John myth? Because the journey became the primary source of popular information about the East for more than two centuries. Polo's writings were widely distributed after being first printed in 1477 , and they made no mention of the Christian kingdom believed to lie to the east. This resulted in the mythic kingdom in some cases being pushed down into what is modern India, but more commonly Prester John became associated with Africa. Thus, as Marco Polo created motivation for the Age of Discovery, Prester John assumed the status of a mythic leitmotif that ran concurrent with the Age. In a very real sense, Prester John personifies the edge of the zone of ignorance for the Europeans, much the same way the Northwest Passage framed exploration of North America ( $c f$., Carlson 2002). Prester John would haunt the European consciousness for nearly four centuries, a blend of myth and fact, desire and reality, hope and rumor. Whitfield (1998:31) echoes this, noting that "the figure known as Prester John, ruler of a mysterious Christian kingdom in the east, would be discussed and sought by generations of European explorers" and who "appeared again and again on maps from the thirteenth to the sixteenth century, shaping the European vision of the world."

Indeed, any map of Africa produced during the three hundred years after Marco Polo was hardly deemed complete without a reference or pictograph of Prester John in the vicinity of Abyssinia. Homem (1558) provides a striking visualization of the dominance Prester John had in the consciousness of Europe. Even though the map is of the Indian Ocean, the viewer's eye is drawn to the Horn of Africa where one is presented with a regal figure enthroned in the mountain fastness of the continental interior. Holding a staff topped by a cross, Prester John gazes almost longingly across the tents of the lowland African people toward the Portuguese ship on the Indian Ocean. Enticingly, the headwaters of the Nile River reach like grasping fingers into the Ethiopian interior, offering another possible route by which Europe could reach the fabled land.

\footnotetext{
${ }^{5}$ Another motivation for this trip, in addition to that of trade with Cathay, was that the Mongols were not clearly religious and carried out a ruthless campaign against the Muslim World during 1256-1260, thus offering the possibility of another ally in Europe's ongoing conflict with Islam.
} 
Figure 2: "Chart of the Indian Ocean". Homem, Diogo (1558). "Chart of the Indian Ocean" [Map] in Queen Mary's Atlas, The British Library, shelfmark MS 5415A, reproduced in Leo Bagrow (1966) History of Cartography, revised and enlarged by R. A. Skelton. Cambridge, MA: Harvard University Press, pp. 144-145 (inset).

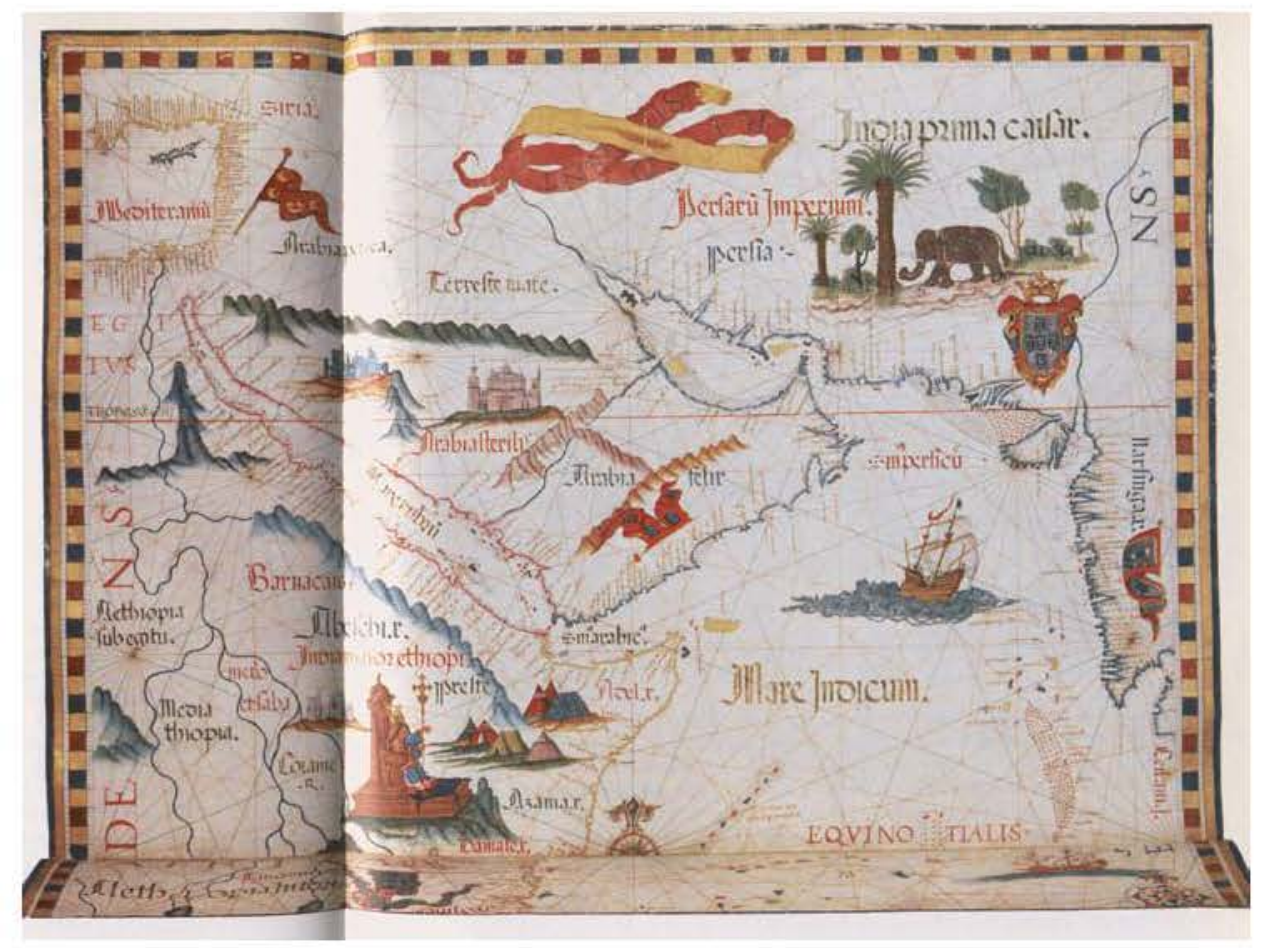

The discussion of Prester John seems a convenient place to leave the discussion of Abyssinia in antiquity, at least for the time being. Plainly, Abyssinia long-existed on the edge of Europe's information network (IN), shrouded in myth and rumor which was then embodied in Prester John, beginning in the twelfth century. Seventeenth century representations of the region remove the ephemeral figure of Prester John, but continue to refer Abyssinia as the "Empire" or "Kingdom" of the Prester; he is the framework within which the area is conceptualized. At what point does Prester John become supplanted by economic or other political-military concerns? Or, more accurately - as Axum had an established trade relationship with the Mediterranean system when did Europe expand into the existing trading systems that involved Abyssinia?

\section{Wallerstein, the World-System and Abyssinia}

Wallerstein is concerned with later aspects of Abyssinian/Ethiopian development. Because his vision of the world-system is that of European expansion outward, earlier interactions with Ethiopia are neglected or downplayed. This is further complicated by the relative positioning of Abyssinia in context of larger systems of interaction: the region is adjacent to successive trading systems and its political success derived from an ability to exploit inter-regional -- or crosssystemic -- trade. To illustrate: 
In the twelfth century, the Eastern Hemisphere contained a series of empires and small worlds, many of which were interlinked at their edges with each other. At that time, the Mediterranean was one focus of trade where Byzantium, Italian city-states, and to some extent parts of northern Africa met. The Indian OceanRed Sea complex formed another such focus (Wallerstein 1974:17).

As discussed, Abyssinia née Axum was a peripheral part of the early Mediterranean world economy through linkages with Egypt. But this relationship to the Mediterranean was also predicated on the position of Abyssinia vis-à-vis the Red Sea trade, and the neighboring Indian Ocean complex. Further, Abyssinia was situated to extract benefit from the trans-Sudan Sahel trade networks of the African interior as goods traveled to and from the coastal ports. It is precisely because these early world-economies were interlinked at their edges that Abyssinia developed, producing the "Golden Age of the Solomonic Dynasty", ca. 1270-1500 (Marcus 1994:17-30). Abyssinia was the nexus by which these world-economies were hinged.

The import of these linkages becomes clearer when one examines Portuguese expansion and its impact on the Levant's "decline", as it mirrors several structural features of the trade exploited by Abyssinia. With Portugal's entrance into the Indian Ocean, the eastern Mediterranean spice trade went into decline due to "the structural diversion of trade and hence its noninclusion in the expanding European world-economy" (Wallerstein 1974:325). This is well and good, and indicates that regions favorably impacted by the "structural diversion of trade" should be included in the European world-economy - yet this neglects the same consideration be given to regions negatively impacted. Indeed, after 1500 the Indian Ocean was essentially a Portuguese lake:

In any case from about 1509 when the Portuguese defeated the Egyptian fleet at Diú, the Portuguese navy held 'uncontested hegemony' in the Indian Ocean. In addition, during the sixteenth century ...Portuguese traders were to be found not only there but in the China Sea, on the coasts of Africa east and west, in the south Atlantic, in Newfoundland, and of course in Europe. 'Thus, present everywhere, a Portuguese economy' (Wallerstein 1974:327).

If the region is under uncontested Portuguese hegemony and reflects the presence of a Portuguese (thus European) economy, why would it not be part of the European world-economy?

There are two reasons, one theoretical and one practical, that the Indian Ocean worldeconomy - hence Abyssinia peripherally - is not part of the European world-economy. Practically, Portuguese control in the Indian Ocean complex was maintained quite simply, by monitoring access, not production. Two squadrons were used in conjunction with a network of fortresses. One fleet patrolled the western coast of India and the other blocked the Red Sea. Thus, the empire-building trade astride which the Solomonic Dynasty grew was diverted from the traditional Red Sea - Egypt and trans-Sudan networks and began to flow around Africa under 
Portuguese control. ${ }^{6}$ Just as the Levant trade was forced into decline, Abyssinia experienced similar deleterious effects; it is not coincidental that the period from 1500 to 1769 is associated with the decline of the Solomonic Dynasty (Marcus 1994:30-47).

The theoretical reason for non-inclusion comes down to dominance. This reflects the overly Eurocentric nature of the Wallersteinian world-system. Reminiscent of the "favorable order" required for incorporation, the Indian Ocean is external because:

To appreciate why we do not consider the Indian Ocean trading area to be part of the European world-economy despite the fact that it was so completely dominated by a European power, we must look successively at the meaning of this dominance for the Asian countries affected, its meaning for Europe, and how it compares with those parts of the Americas under Iberian rule (Wallerstein 1974:328).

Because the Portuguese took over a pre-existing trade network, they did not establish political dominance. Therefore trade was carried on in a framework established by the Asian nations, and the "social organization of the economy as well as the political superstructures remained largely untouched" (Wallerstein 1974:331). Essentially, if nations or external actors can possibly set the terms of trade, Wallerstein defines them as outside the system. Successful resistance implies externality.

This illustrates some conceptual problems that emerge in the discussion of inter-systemic trade. What happens when two previously independent systems come into contact with one another? If the polity being contacted can negotiate its own terms, should it be external to the system as no reorganization of the economy is enacted? If so, this mandates that, by definition, the "world-system" being discussed is one of European dominance. Thus, there is no notion of "equal exchange" or mutual benefit; the process of incorporation becomes synonymous with the process of European subjugation. This is evident in the discussion of the difference between the Iberian experience in Asia to that in the Americas: "Iberia establishes colonies in the Americas, but trading-posts in Asia" (Wallerstein 1974:335, emphasis in original), meaning "that the Americas became the periphery of the European world-economy in the sixteenth century while Asia remained an external arena" (1974:336, emphasis in original). This seems counterintuitive - as there was a developed economy in place in Asia, should that not more easily become linked to the expanding European world-economy since an economy does not have to be created from scratch? The benefits have to accrue to Europe, not Asia, thus shifting to a political definition of the system.

By minimizing external agency (i.e., political power in the external arena), Wallerstein unnecessarily hamstrings the notion of the expanding world-system with a shift from defining characteristics based on economic factors (i.e., bulk goods) and their production to political control and social dominance. This runs directly counter to the conception of the world-system as a process "based on the fact that the economic factors operate within an arena larger than that which any political entity can totally control"' (Wallerstein 1974:348). By ignoring the non-

\footnotetext{
${ }^{6}$ Enticingly, a subsidiary stop for Portuguese goods was located at Aden. But these goods were bound for the intermediate markets of Malacca, Calicut, and Ormuz, not ports on the Red Sea coast (Wallerstein 1974:327).
} 
European political entities involved in the larger arena of economic exchange, and by defining the system as that within which European nations exert political dominance, the complex process of incorporation is oversimplified. This still leaves us with a historical shell-game: whither the 'pea' that is Abyssinia?

Since the Indian Ocean - Red Sea network is external to the system despite Portuguese expansion, when does Abyssinia/Ethiopia become part of the world-economy? The answer is compounded by the diversion of trade under the Portuguese. As an adjacent arena that was partially dependant on trade from the larger Red Sea network, Ethiopia experienced a period of decline to around 1769. This is related to the close relationship between the Ottoman Empire as an economic system and the Red Sea trade. As the Ottoman Empire came under increased pressure from European competition and dominance of the Indian Ocean, this was felt throughout the region:

Red Sea commerce had eroded, owing to the onset of the political illness that was to make Turkey the sick man of Europe. The Ottoman Empire, as an economic system, was deteriorating along its periphery, especially in the Red Sea-Indian Ocean. As the region's trading networks were disrupted, demand for Ethiopia's products slackened. Intra-Ethiopian trade continued, with regional products, such as wool blankets from Menz, salt from Eritrea, and coffee from Kefa, being marketed everywhere. (Marcus 1994:49)

Everywhere, in this case, means within the intra-Ethiopian trading network. Ethiopia declined and entered a period of political erosion, drifting out of the system toward the zone of ignorance.

It is during the period between 1769 and 1855 that the region underwent a political and economic transformation ( $c f$. Marcus 1994:48-62) followed by an "imperial resurrection". It is also the period of 1750-1850 that Wallerstein (1989:127-190) identifies with the incorporation of new zones into the world-economy. It is hardly coincidental that a period of drastic worldsystemic expansion corresponds to a period of transformation in the Ethiopian system. As the Ottoman Empire was being drawn into the world-economy, ripples of change were similarly felt along its periphery. Yet Wallerstein only argues that central portions of the Ottoman Empire are being incorporated, so the period from $1800-1850$ is the Wallersteinian period of incorporation. As we see, the process started much earlier.

\section{ETHIOPIA AND EUROPE}

What happens during the period of transition from existing as myth to the period of being inside the system? Here, the notion of nested boundaries of world-systems networks comes in handy. The 'grooming' process of systemic enlargement occurs as new regions or systems are contacted, and should be viewed as the information and prestige goods networks becoming partially coincident. Truth begins to be sorted from fiction and the relative "worth" of new regions is explored. Accordingly, rumors and myths of wealth also exert an inordinate influence on decision making. The process of 'incorporation' begins as prestige goods, luxuries, and highvalue commodities are systematically exchanged or extracted. Relations are more formalized via official government activity and become regularized, thus bringing the regions into a political- 
military network of interaction. The peripheralization process, then, refers to the greater exchange of bulk goods and an increase in interaction resulting in the regions existing in a mutual bulk goods network. It is only this most narrow, "bulk goods network" that is solidly considered to be "within the system". Examining local history makes systemic linkages more evident. Marcus (1994) provides a useful rubric for the consideration of modern, post-Axumite Ethiopia: dynastic rise (to 1500), decline (to 1769), transformation (to 1855), and eventual imperial resurrection (to 1877).

\section{Golden Age of the Solomonic Dynasty (1270-1500)}

A principle element in the history of Ethiopia is its identity as a Christian kingdom. In turn, this identity creates a dual-natured 'myth'. On one hand, it became necessary to maintain an internal political lineage of monarchical origin. On the other, this formed the basis for the Prester John myth of external, European re-creation and consumption. That Ethiopia was a Christian state is not in question. The origin of this state, however, is more a product of revisionist history used for political consolidation and legitimation. Not unique to Ethiopia, similar myths are central to the growth of most nationalist movements. Yet this particular myth of origin plays a more central role in the relationship Ethiopia develops with the outside world, and proves integral to the rise of the Solomonic dynasty in the thirteenth century.

While rumors of the existence of Prester John's fabulously wealthy and strategically placed Christian kingdom circulated in Europe in the twelfth century, the political reality in Ethiopia was more fractious. National unity and dynastic authority was under constant challenge. By the late thirteenth century a small Christian kingdom in northern Shewa, having grown rich by diverting trade, rebelled. The king, Yekuno Amlak, gained support by promising to make the church a semi-independent institution and defeated the Zagwe monarch in 1270 - killing the Zagwe king in front of the altar of a parish church. To overcome resistance to his usurpation, Amlak and his supporters began to circulate a story about his descent from King Solomon and Makeda, Queen of Saba ("Sheba"). Thus, the Solomonic line was "restored", legitimacy and continuity of rule reinforced, and the basis of the Prester John myth solidified (Stevens 1981, Marcus 1994). ${ }^{7}$

Faced with Muslim encirclement, the new Solomonic regime carried out continuous military activity against encroachment by the seaboard-based Muslim states. This military activity was balanced by internal religious development and literary renaissance, resulting in the merger between church and state. Under the rule of Amda Siyon (r. 1314-1344), Ethiopia expanded southward and the empire consolidated. Siyon reorganized provinces into smaller administrative units controlled by strategically placed garrisons, who in turn spread the gospel as well as the Pax Ethiopica. The garrisons kept an eye on the local gult, or fief, administrators who

\footnotetext{
${ }^{7}$ This myth of origin has even become officially sanctioned. First codified in the Kebre Negast ("The Glory of Kings") in the early fourteenth century, the story of origin was cobbled together by six scribes, who "blended local and regional oral traditions and style and substance derived from the Old and New Testaments, various apocryphal texts, Jewish and Islamic commentaries, and Patristic writings. The Kebre Negast's primary goal was to legitimize the ascendancy of Emperor Yekuno Amlak and the 'restored' Solomonic line." The Ethiopian constitution of 1955 reinforces this, stating in Article 2 that the ruling line descended from Menelik I, son of the Ethiopian queen Makeda and King Solomon (Marcus 1994:17). Myth has transcended and become government-sanctioned "fact".
} 
were responsible for collecting taxes, supplying soldiers in wartime, demanding service from subjects, and maintaining authority in the name of the monarch. As long as taxes were paid and order maintained, these local gult-lords enjoyed considerable autonomy (Marcus 1994:17-19).

By the late $1320 \mathrm{~s}$, Muslims tired of Christian domination and heavy taxes managed to unite and exploit a decade of royal neglect. Eventually put down, this rebellion reflects the constant threat Islam posed to Ethiopia. As a response, Christianity became an internal and external source of defense. The rule of Emperor Zara Yakob ${ }^{8}$ (r. 1434-1468) exemplifies this dualistic nature of Christianity. Internally, he reformed the church with the goal of greater theological uniformity. The king endowed monasteries and churches that supported the reformed ideology of a unified state, often with property confiscated from defeated rulers. This solidified the monarch-church relationship and increased the integration of the clergy into the larger political structure of the kingdom (Marcus 1994:23-5).

Externally, the nature of Christianity under Zara Yakob is relevant for systemic development. Interested in restoring the country's international relations, he sought to renew Ethiopia's contact with external Christian powers. Earlier kings (e.g., Widim Arad, 1297-1312; Yeshaq, 1414-1429) had previously tried to send missions, which further fed the Prester John myth in Europe. Limited contact with Western and Byzantine regions was tenuous, via the Coptic Church in Egypt, which was responsible for the assignment of Ethiopian archbishops. Ethiopian monks from Jerusalem even attended the Council of Florence in 1441, where the Pope was seeking to reunite the Eastern and Western Church (Munro-Hay 1991, Stevens 1981). Embassies sent to Cairo in 1443 and 1447 were reported in Europe, and throughout the 1440s Zara Yakob tried to break the Muslim control over European access into Ethiopia. Access was blocked by Egypt, determined "not to let the Europeans travel to Ethiopia, lest they sell modern firearms to the emperors" (Marcus 1994:26). To get around this blockade, in 1448-1449 Zara Yakob successfully settled military colonies in what is now Eritrea and diverted trade from the highlands to the new ports on the coast (Marcus 1994, Munro-Hay 1991). In world-system parlance, this is clear evidence of the region existing as a contested periphery, caught between the Christian and Muslim trading systems.

Word of Zara Yakob's success spread to Europe, fanning the flames of the Prester John myth and raising hopes that a Christian ally would be able to break Muslim power in Egypt and Arabia. Rumors about the mythic kingdom had long circulated, and supplemented Henry the Navigator's maritime push around Africa in the early 1400s. For example:

The deliberateness of what the Portuguese were doing during these years is attested by a remarkable document, the Papal bull Pontifex Romanus of 1455 . It is effectively the charter of Portuguese imperialism, granting them a monopoly of navigation and trade between Cape Bojador and the Indies. The church decreed that those who died in the course of these voyages would be regarded as having died in the course of a crusade and therefore receive a plenary indulgence for their sins. The aims of winning land and trade from the Moslems and linking with Prester John were kept constantly in view (Whitfield 1998:36).

\footnotetext{
${ }^{8}$ Alternately spelled Zara Ya'qob (see Munro-Hay 1991).
} 
Portuguese sailors, soldiers, even artisans ${ }^{9}$ and priests began to penetrate into Ethiopia in the latter half of the fifteenth century, reintroducing Ethiopia to Europe and bringing the networks of the two systems into greater contact (Marcus 1994, Munro-Hay 1991).

By the start of the sixteenth century, Ethiopia was a developed state at the heart of a significant regional sub-system. It was a feudalistic conglomerate state centered on the northern highlands with a population sharing linguistic, religious and economic similarities. Beyond this core region was a ring of more recently conquered provinces with a similar administration and whose people were nominally Christian. At the outer periphery were tributary states with traditional rulers governing peoples that were culturally distinct, but often economically tied to the heartland. As long as the core was profitable and stable, the system could be held together. With the weakening of the central state toward the end of the fifteenth century, revenues decreased, garrisons withered, and increased friction between church and crown resulted in a reversion to Christian heterodoxy (Marcus 1994).

Pankhurst (1997) clarifies the mutually-beneficial economic relationship between the borderlands and the core of the Ethiopian state, as political stability promoted trade. Taxation and tribute was important for the central state, but also for the political entities nearer the periphery as they were able to levy duties on goods carried from the interior or the coast. Nevertheless, the trade of the interior was heavily dependent on the borderlands since "all such commerce passed either through the Red Sea or Gulf of Aden ports, on the northern or eastern periphery, or by way of Sudan, on the western borderland" (Pankhurst 1997:432). The type of goods carried reflected the importance of the periphery: "Gold, ivory and civet came largely from the rich lands on the south-western periphery, while myrrh and other resins originated in the arid lowlands in that of the east". The borderlands were also a major source of slaves, which were "one of the region's most valuable exports" (Pankhurst 1997:432; cf. Lewis 1990). The currency of the interior - the bars of rock salt known as amolés - originated in the salt plains of the northeastern borderlands, and the gold for international trade was primarily obtained from the western and southwestern periphery. Control of the trade routes, and especially access to the sea, was therefore crucial to the maintenance of empire. This was reinforced with the arrival of Europeans and the coincident introduction of firearms that became crucial to determining the balance of political power throughout the region (Pankhurst 1997; Marcus 1994).

\section{Dynastic Decline (1500-1769)}

Is it mere happenstance that the beginning of Solomonic decline coincides with the emergence of European power in the Indian Ocean? No, though it does possess a certain amount of historical irony. The arrival of the Portuguese in the Indian Ocean exacerbated internal political problems for Ethiopia. Because one Portuguese squadron blocked the Red Sea trade and no longer allowed Muslim traders free access to the Indian Ocean network, disruptions were felt in the Red Sea economy. Pressures in the Muslim territories of the Ethiopian hinterlands, which had been building for years, were made worse by the disruption of trade revenues. As an empire dependent

\footnotetext{
${ }^{9}$ While most travelers were turned away by Egypt, some managed to get through and even impacted local artistic styles. The painter Niccolo Brancaleone, "whose fluid renaissance style influenced traditional Ethiopian artists to graft a more natural modeling of faces and bodies onto their previously stylized religious scenes" (Marcus 1994:28).
} 
on exploiting trade routes, which were in turn largely dependent of the Red Sea trade network, Ethiopia was facing an existential crisis by the beginning of the sixteenth century. This crisis was a direct result of the Portuguese incursion into the Indian Ocean.

Europe still identified the Ethiopian region with the image of Prester John and knew relatively little about the interior of the country. This changed with the arrival of priests and official Portuguese envoys after the turn of the $16^{\text {th }}$ century, though books and published accounts of the region still framed Ethiopia in the context of Prester John. For example, Martin Waldseemüller's "Carta Marina" exhibits the confluence of the expanding European information network with that of the Ethiopian system. Prester John resides in the Horn of Africa, signified as such by the text above the figure with the cross. The African coastline is reasonably accurate, but the interior of the continent is largely vacant. Place names are drawn inward to give the illusion of fullness; additional textual notation is included -- thus reaffirming the importance of treating maps as historical texts and as a methodological tool for measuring information networks. Mountains surround the highlands of Ethiopia, even stretching erroneously across the Somali lowland plains. The Red Sea is also a combination of fact and fancy, in turn reflecting Europe's lack of dominance in its confines. Many islands are positioned throughout the Red Sea, it is given an east-west orientation that drastically diverges from its more accurate north-south run, and the width of the sea is overstated in context of its length. These distortions are partially the product of the type of map employed - a plane-chart based on a simple square grid - which was already becoming outdated by the turn of the sixteenth century. Nevertheless, it still reflects the European "view" of Ethiopia.

The Ethiopian emperor faced with pending crisis at the turn of the $16^{\text {th }}$ century was Lebna Dengel (r. 1508-1540). Partly inflamed by European Christian expansion into the Indian Ocean, Muslim tension in northwest Africa increased. Emperor Dengel had to deal with non-Christian nomads expanding their range along the south, particularly the southern Oromo. The Muslim states along the Red Sea also became agitated, partly because of a perceived decline in central Ethiopian administrative control and partly because of external support from the Ottomans, who began to introduce firearms and new tactics to the region in an effort to stave off competition from the Christians. The indirect result of European arrival in the Indian Ocean was decreased trade and disruption of patterns of exchange, which led to a lack of central administrative control and capacity, followed by demands in the periphery, which led to a jihad in 1527 . The periphery quickly fell to the forces of Islam, and the Emperor and his army were forced to retreat into the highlands of the interior (Marcus 1994, Munro-Hay 1991).

Lebna Dengel died in 1540 , but he may have ensured the survival of Ethiopia as a Christian state sending a plea for help to Europe. The call reached Portugal in 1535, by which time even the interior of Ethiopia was under Islamic control. It was not until 1541, after six more long years of war, that four hundred musketeers under the leadership of Cristovão da Gama arrived. ${ }^{10}$ The Muslim leader, Ahmad ibn Ibrihim al-Ghazi, ${ }^{11}$ turned to regional Ottoman authorities who "provided nine hundred Muslim, mostly mercenary, musketeers and ten cannon" (Marcus 1994:34). After much fighting, Ahmad ibn Ibrihim was killed in 1543 and the Muslim forces left Ethiopia to the Christians, led by Emperor Galawedos (r. 1540-1559) (Marcus 1994:32-35; Munro-Hay 1991). Notably, while this war served as the introduction of firearms

\footnotetext{
${ }^{10}$ The son of noted explorer Vasco da Gama, Cristovão was captured and beheaded in 1542.

${ }^{11}$ Referred to as Ahmad "Gran" - the "left-handed" - Imam Ahmad was known for his Islamic Puritanism.
} 
into the region and they proved crucial to victory, firearms remained scarce until the early $1800 \mathrm{~s}$ (Pankhurst 1965:26).

Figure 3: Carta Marina [detail]. Waldseemüller, Martin (1516). "Carta Marina" [map], in Peter Whitfield (1994) The Image of the World, London: The British Library, pp. 54-55.

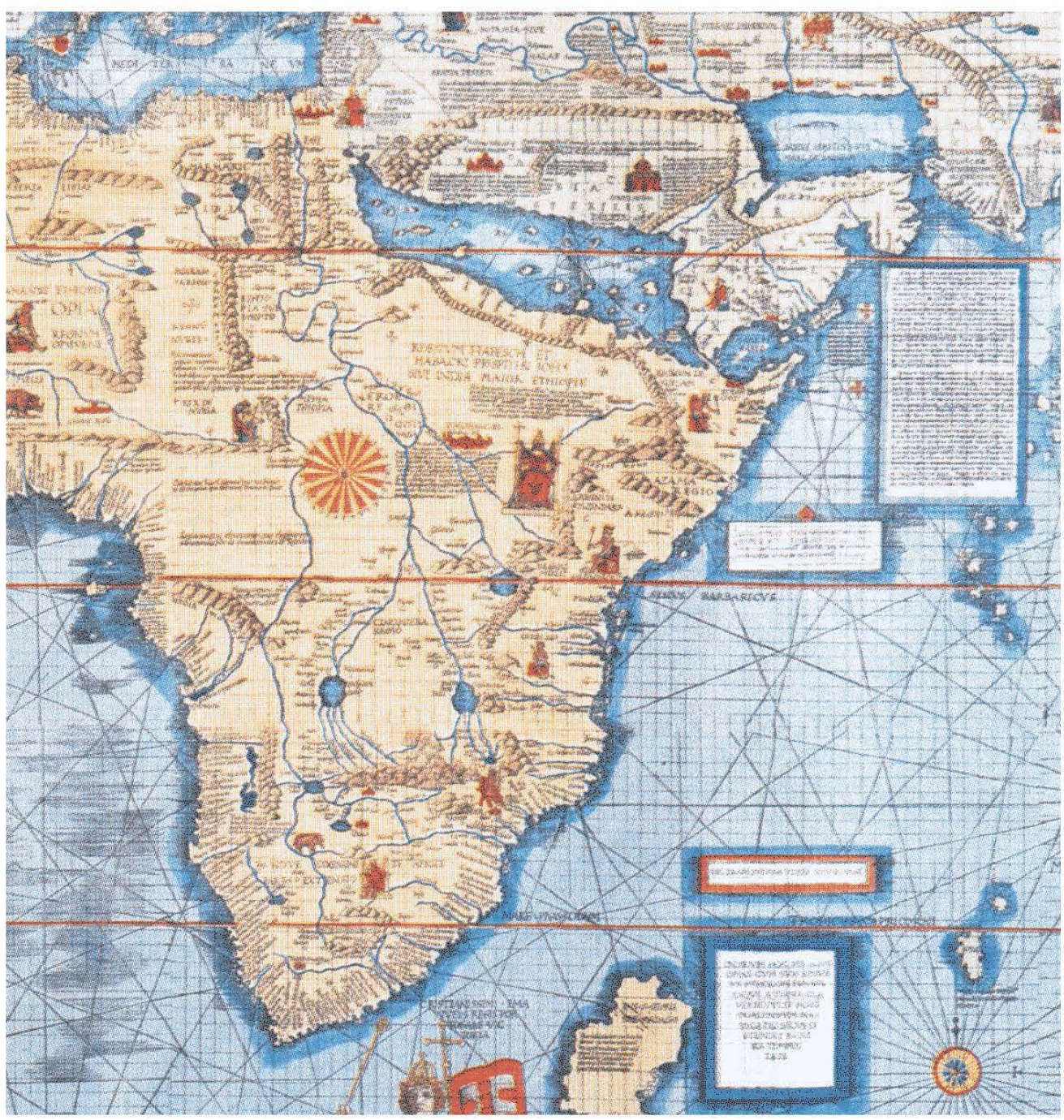

The conflict between the Christians and Muslims in Ethiopia is important for more than just the aspects of religious conflict. It is indicative of the region's status as a 'contest periphery' and it marks a fundamental shift in the position of Ethiopia in the larger context of the worldsystem, as evidenced by the supply of musketeers. No longer does Ethiopia benefit from its position as a bridge between two interdependent networks of exchange, able to build political stability based on the extraction of economic surplus from trade. Instead, it has become a 
'periphery of contention' between two counter-systemic superpowers ( $c f$. , Allen 1997, Cline 2000). With Istanbul competing with Lisbon for hegemony of the Indian Ocean, Ethiopia became a contested ground between Europe and the Ottoman Empire. Religion was perhaps the most obvious symptom of this divide, but it was a systemic conflict more than a strictly religious one. This becomes evident if we look at the resulting socio-political situation within Ethiopia.

Even though a consolidated facsimile of the Solomonic empire was fashioned after the victory, it lacked the deep strength of the earlier polity. The Christian core of the Ethiopian state was further divided as Portuguese priests sought to undermine the local Orthodox Church and promote conversion to Catholicism. By the mid-1600s, the Ethiopian church-state relations were characterized by fragmentation and sectarianism, resulting in a series of rebellions and uprisings and the eventual rejection of Roman Catholicism. In turn, this meant that the Solomonic state became limited to the highlands of Abyssinia. The Jesuits, and later all Roman Catholic missionaries, were expelled. Effectively, by refusing to embrace the Roman Catholic Church of the Portuguese, Ethiopia managed to withdraw from existing in the periphery of contention between Portugal and the Ottomans. This 'negotiated peripherality' (cf., Kardulias 1999, 2007) also contributed to a period of isolation that followed for the next 200 years (Marcus 1994; Stevens 1981). Incorporation into the European system necessarily meant dissension in Ethiopia; religious division is merely one aspect of this process. While incorporation is oft thought as consolidation, it is only consolidation if it benefits the expanding system. Necessarily, it is a force of 'creative destruction' that eliminates or reduces contending sources of authority or power. This, then, creates significant fissures in societies on the periphery that are in the process of being absorbed, groomed, altered, or otherwise incorporated.

Political isolation does not mean that Ethiopia was not connected to the larger systemic networks, as the regional sub-system of Ethiopia continued to be active. While the political reach of Ethiopia consolidated around the new capital of Gonder ${ }^{12}$ in the Christian north, the economic reach of Ethiopia continued to be extensive, and influenced by European demands.

The highlands exploited the hinterland's primary products, connecting Ethiopia's economy to the commerce of the Red Sea and Nile valley. A complex caravan network linked Mitsiwa and the interior, and Gonder became a regional center, doing business with Sennar and Fazughli for slaves and gold bought and paid for with coffee obtained from Enerea. The market for Ethiopian beans grew considerably during the last quarter of the seventeenth century as Yemen, a major trading partner, sought increasing amounts of coffee for transshipment to Europe to satisfy burgeoning Western demand (Marcus 1994:40).

Coffee became an important linkage to the outside world. A common export, there were unsuccessful attempts by Europeans to obtain coffee directly from Ethiopia (Aregay 1988). With the growth of coffee plantations in European colonies this became superfluous, though Ethiopia continued to contribute to the Red Sea coffee trade during the eighteenth century.

Overall, the Gonderine period is one of political decline. The religious divisions within the Ethiopian state continued, which led to the eventual aristocratization of encroaching Oromo from the south as an attempt to stabilize increasingly tenuous authority in the region. This only fueled interior division as regional feudal leaders continued to challenge the monarch, who increasingly became dependent on their generals. Abyssinia slipped into disarray, and provincial lords increasingly went their own way as the emperor's power at Gonder became limited to the

${ }^{12}$ Or Gondar, Ethiopia has a tradition of transient capitals (See Horvath 1969). 
immediate vicinity of the royal compound. Predictably, civil war broke out in 1766 between provincially divided interpretations of Ethiopian Christianity, leading to a period of feudal anarchy, which would last until 1855 (Crummey 1975, 1990; Crummey and Shisagne 1991).

So where is Europe during this period? How is the expanding European system conceptualizing Ethiopia and where does it sit in terms of European networks of interaction? After coming into initial contact, and even entering into the realm of political-military interaction with the Portuguese supply of musketeers and in 1541, Ethiopia rejected the subsequent phase of cultural incorporation as embodied by the dispute with the Jesuits and Roman Catholics. The expulsion of the Europeans meant that little first-hand knowledge of Europe was directly available in Ethiopia, though the region was still part of the Red Sea trading network and the prestige-goods network of the European system. As the political situation became unstable and Ethiopia declined, it stagnated on the active fringe of the European system, sliding back toward the realm of myth and fantasy.

Figure 4: "Presbiteri Iohannis". Ortelius, Abraham (1573). "Presbiteri Iohannis..." [map], in Theatrum Orbis Terrarum, Antwerp. Image from Peter Whitfield (1998) New Found Lands. London: The British Library, pp. 165. Shelfmark Maps C.23.e.12.

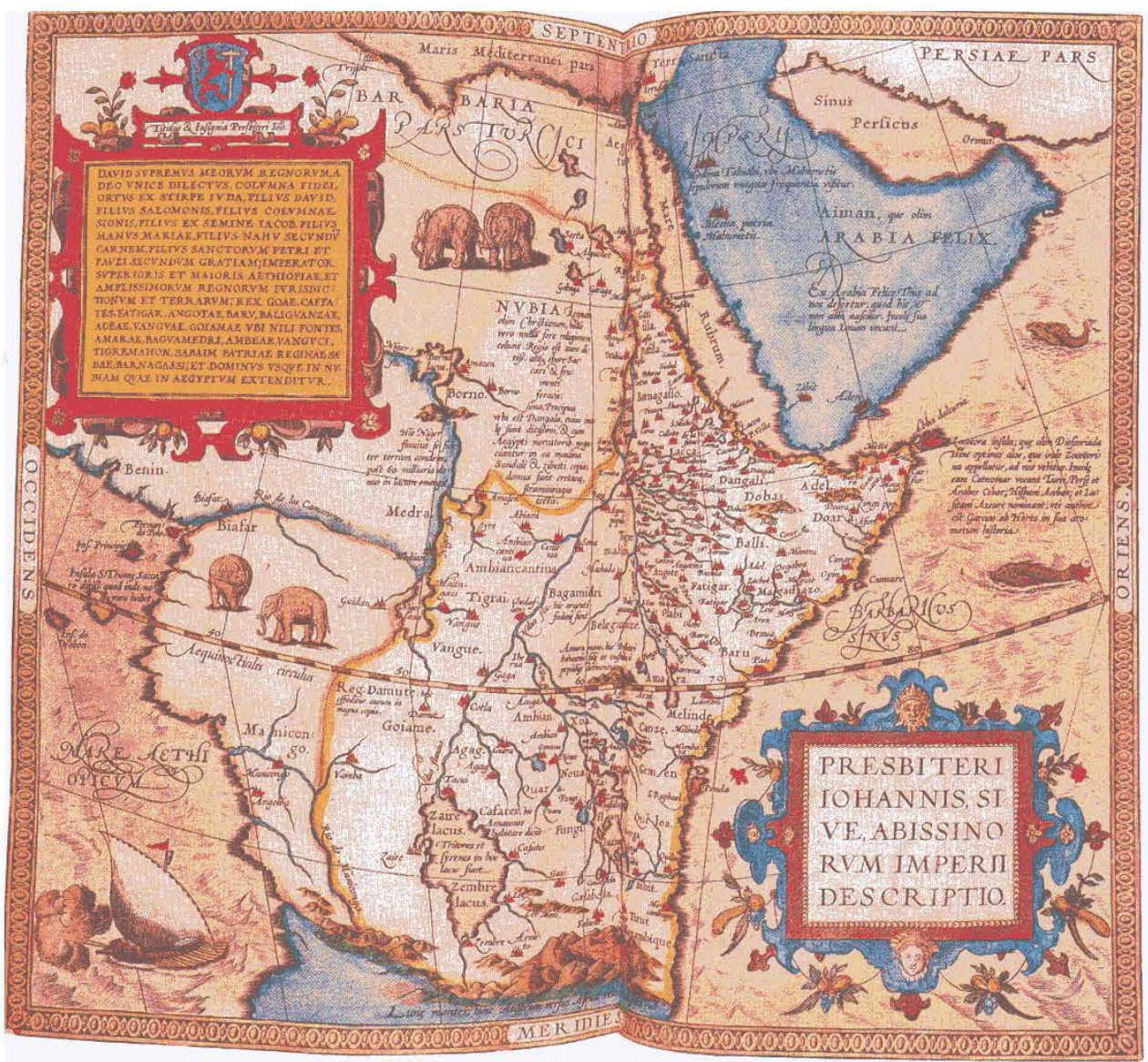


This is evidenced by the way the region is represented throughout the sixteenth and seventeenth centuries. Gerard Mercator's world map of 1569 is insightful, as "Mercator conceived his map as an intellectual document to be read and studied" with many lengthy texts, including a "demythologizing account of the Prester John legend" (Whitfield 1994:66). Reflecting Mercator's extensive research into travel narratives, geographical literature, and navigational reports, the map was published thirty years after his previous world map, and may be viewed as a comprehensive encapsulation of European knowledge. While relatively free of the space-filling figures and fanciful animals populating the continental interiors of earlier works, Ethiopia is still conspicuous precisely because of the Prester John figure in the African interior. This reflects European knowledge concerning Ethiopia: reference to Prester John, mountainous, with some realization that it may be related to the source of the Nile.

The static nature of Ethiopia in European awareness is clear with only a cursory examination of period maps. Abraham Ortelius produced a widely distributed and copied version of the Kingdom of Prester John in 1573.

Ortelius' Theatrum Orbis Terrarum is described as the first modern atlas, and went through 32 editions after its initial publication in 1570. Based partially on reports of the Portuguese embassies, some modern names are recognizable (viz., Goiame and Tigrai). The overall extent of Abyssinia is greatly exaggerated and river drainages are drawn for effect. Nevertheless, because of its wide publication, this became the dominant image of the region for the next two centuries.

Figure 5: "Abissinorum". Hondius, Jodocus (1613). "Abissinorum sive Pretiofi Ioannis Imperiu" [Map], Amsterdam. First edition published in 1606.

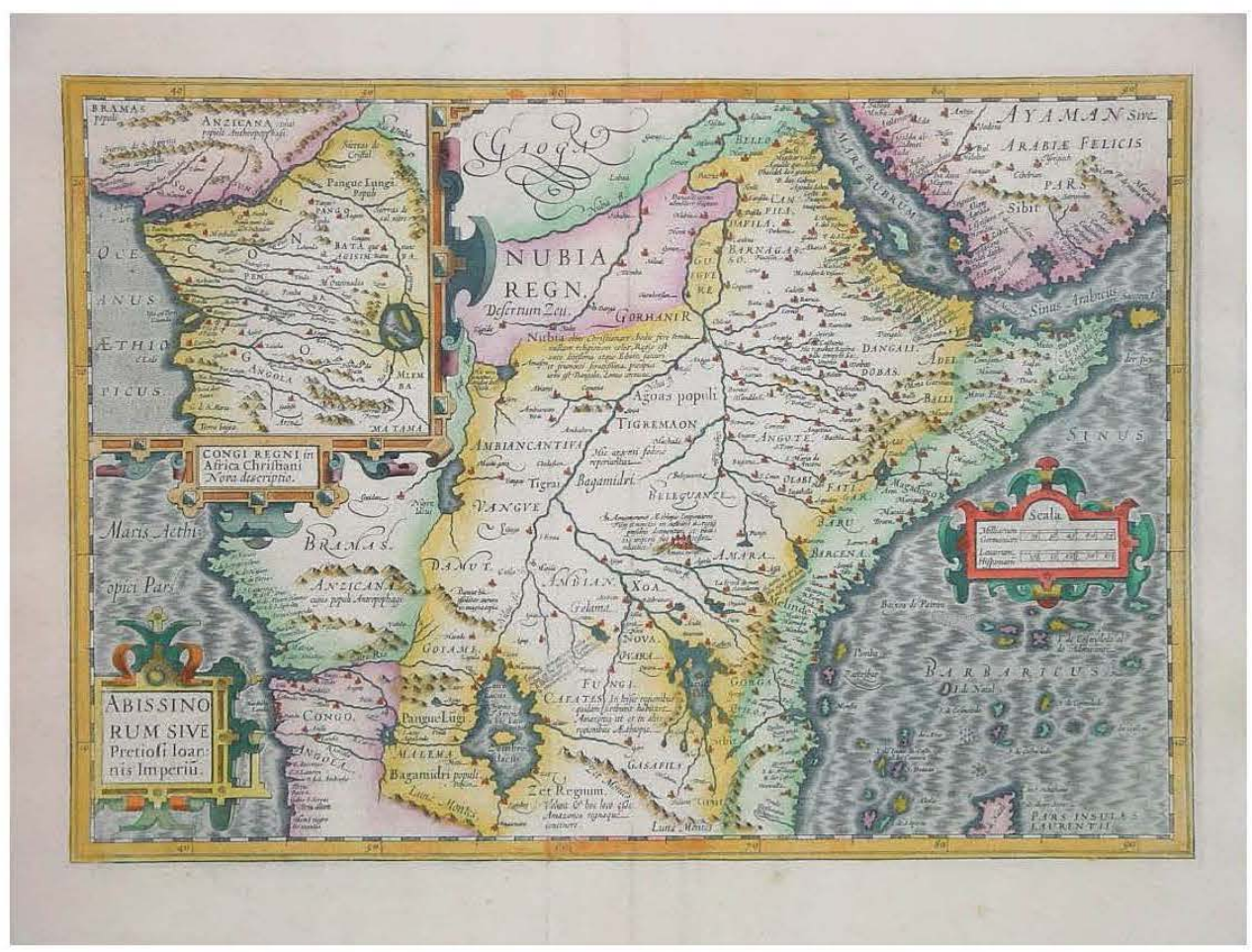


Forty years later, Hondius (1613) is essentially the same representation. The only major differences are in presentation, not content. Coloration and use of cartouche or text box differs, but the gross exaggeration of Abyssinia is the same. An interesting additional "detail" lies in the heart of the largest lake envisioned as the origin of the Nile - Hondius innovates and tosses in an island. One is left to ponder, is it better to have some information depicted, however inaccurate, or rather no information? Stylized images of Prester John have disappeared from cartographic depictions of Abyssinia, yet the region and its Coptic Christian rulers - who were now said to be descendants of the original Prester John - continued to be conceived in the same intellectual framework: Christian, mountainous, and largely inaccessible. Though by the mid to late $1700 \mathrm{~s}$, efforts to reach the head of the Nile had pushed its headwaters to the south, with Lake Tana remaining the primary source of the Blue Nile. ${ }^{13}$

\section{Transformation \& the Zamana Masafent (1769-1855)}

The next period in Ethiopian history essentially kick-started the grooming process once more, though not without a painful transition period of political consolidation. Systemically, Ethiopia began to move from the zone of ignorance, through the external arena, into a state of becoming nominally incorporated. Domestically, this period was known as the Zamana Masafent, or "age of princes", and proved to be a time of political and economic reorganization. The assassination of the emperor by the imperial ras $^{14}$ Mikail Sehul in 1769 , ushered in this period of transition (Marcus 1994:45-47). The decline in central authority led to decreased commerce, and times were so bad that nobles even "resorted to such traditionally unsavory occupations as smithing, weaving, and trading" (Marcus 1994:53).

Social innovations also helped the royal lineages survive ( $c f$. ., Crummey 1975, 1990). The alakenat is one such innovation, by which a single individual was endowed with the majority of a family's property and power to be held in trust for the next generation. Other families tied church endowments to the trans-generational support of specific lineages, which helped some to survive and prosper. This had the subsidiary impact of effectively institutionalizing sectarian differences in the church over what would otherwise be secular disagreements over succession. Thus, the theological controversy that had split the country in civil war became transferred to questions of royal lineage and succession (Marcus 1994; Stevens 1981). The royal line was riven, with legitimate contenders and usurping pretenders, so that during the most confused period (ca. 1800) there were as many as six rival emperors. Peasants either left the land or were driven from it, to become brigands or soldiers-for-hire. Power was dispersed and only became more centralized by the second quarter of the nineteenth century as external forces began to make an impact on the highlands and throughout the Ethiopian periphery (Stevens 1981:17-19).

In 1811, Muhammad Ali of Egypt (r. 1801-1848) began a slow expansion into Arabia and down the Red Sea coast, making incursions along the eastern edge of the Gonderine state. Trade

\footnotetext{
${ }^{13}$ For example James Bruce, author of the five volume Travels to Discover the Source of the Nile, arrived in Ethiopia in 1760 and subsequently commented on the political intrigue and bloody dissention.

${ }^{14}$ Ras literally means "head" and is a title of nobility, roughly equivalent to duke. The imperial ras served as the primary head of the emperor's military forces, or commanding general. The assassination was not a unique occurrence, as soldiers helped assassinate Emperor Tekle Haimanot (r. 1706-1708), and imperial guards saw to the poisoning of Emperors Yostos (r. 1711-1716) and Dawit III (r. 1716-1721).
} 
among the Red Sea states revived as Cairo's influence reappeared, and "[d]emand grew for southern Ethiopia's slaves, coffee, hides, skin, musk, and ivory, immediately affecting the north, since trading centers in Shewa, Begemdir, and Tigray were involved in moving the commodities to the sea" (Marcus 1994:54). European powers - notably the British and French - began to show interest in the Horn of Africa and beyond, stimulated in part by the increase of trade goods flowing from the Ethiopian interior. The slave trade proved to be of particular interest, and Ethiopia was once again a periphery of contention between European and Muslim interests.

The slave trade provides a significant basis for understanding the trade linkages of Ethiopia, and it also prompted Muslim and European interest in the region:

Middle Easterners long had bought Ethiopian slaves for their armies, their fields, their homes, and their beds. The habasha slaves, ${ }^{15}$ as they were generally classified, were not usually from Abyssinia but from southern and western Ethiopia, whose societies could not protect themselves against the raiders' firearms. Religious law did not permit Christians to participate in the trade, but they could buy, own, and use slaves; and rulers such as Sahle Sellassie could tax transactions as the slaves were marketed or as the traffic passed through Shewa and its dependencies (Marcus 1994:55).

While the claim that Christians could not "participate" in the slave trade - yet still buy, own, use slaves and tax slave transactions - seems tenuous, the distinction refers to the active collecting and marketing of the slaves. This distinction was taken seriously, as Muslims dominated the slave trade and the slaves came from regions in the south or southwest, allegedly beyond the pale of Christian authority. The slaves were transported across Ethiopia to the coast, where the slave markets often operated in close proximity to markets for "legitimate" goods. A major slave market at Abdul Resul saw 3000-4000 slaves sold annually for "export to Arabia, where a growing economy created increasing demand for slaves" (Marcus 1994:55). Another reason demand increased in the Red Sea region was because the contemporary expansion of Russia into the Caucuses effectively cut off the flow of white slaves out of Central and Western Europe via Istanbul and other Ottoman cities, thus the Muslim states looked elsewhere (Lewis 1990:72-73).

Britain unilaterally outlawed the trade in slaves in 1807 , which provided a convenient front on which Islamic economic power could be assailed. By 1828, the elimination of the slave trade was being used as a criterion for relations with Ethiopia. Ras Sibargardis, the chief of Tigre province in northern Ethiopia, sent his English servant to Bombay, Egypt and England in search of firearms and military support. The chairman of the British Commission for Indian Affairs considered the request favorably, feeling that "Ethiopia could become the emporium of East African trade, and that the Ras if assisted could be expected to annihilate the slave trade" (Pankhurst 1965:26). Thus, after lengthy negotiations a number - estimated around 3,000 - of outdated matchlocks from the stores of the East India Company were forwarded to the Ras in 1831. This was the start of what would be the flow of hundreds of thousands of weapons over the next hundred years, from a variety of sources in addition to Britain (Pankhurst 1965).

So, by the start of the nineteenth century Ethiopia was rapidly being drawn back into the workings of the Red Sea network, which served as a proxy for the European world-system by the

15 "Habasha" translates as "Ethiopian". 
early 1800 s. So how much was known about Ethiopia? How did it appear on European maps? Because of its location on the Nile, previous Portuguese contacts, and in conjunction with new British and French efforts to establish commercial and political relations, Ethiopia was one of the few areas in Africa that was reasonably well-known by 1800 .

This is strikingly clear in Aaron Arrowsmith's rendition of the turn of the century world, and of Africa in particular. Arrowsmith captures a tremendous moment in the development of the world, as Europe sought new spheres of trade and colonization. Yet he embraced the relatively new relationship between cartography and geographical knowledge; Arrowsmith was firmly working in the scientific tradition and his map was inspired by Captain James Cook's voyages of the eighteenth century. It marks a conscious shift to the reflection of the "known" and "reveals the progressive demythologizing of the world map" (Whitfield 1994:114). Accordingly, Arrowsmith's representation of Africa encompasses only what is known to the European world the empty spaces are then striking in their vastness. Gone from Africa are the whimsical creatures and large lakes placed in the interior. Actual knowledge is almost entirely confined to coastal regions or some river drainages, with the notable exception of Ethiopia.

Figure 6: Arrowsmith Abyssinia [detail]. Arrowsmith, Aaron (1808). "Map of the World on a Globular Projection", first published 1794. London: A. Arrowsmith. Electronic image courtesy David Rumsey Historical Map Collection, copyright Cartography Associates: http:/www.davidrumsey.com/maps924.html.

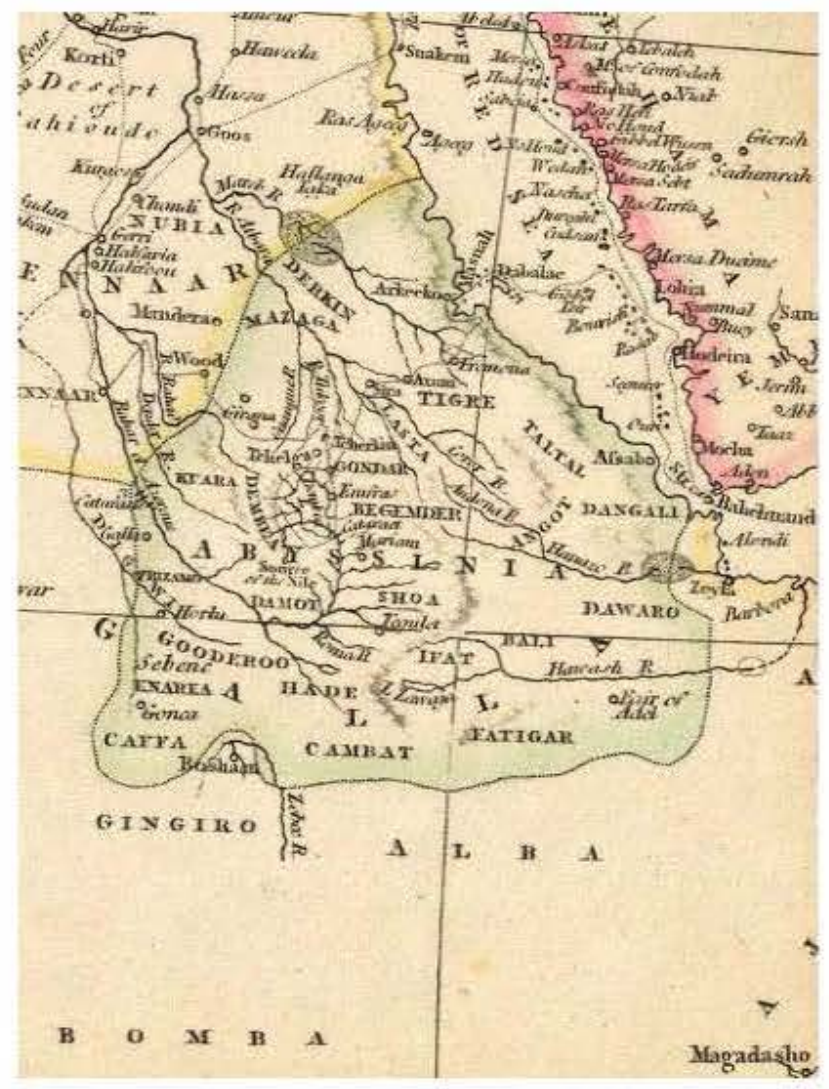


The representation of Abyssinia is remarkable, even more so when considered in light of the rest of Africa. Abyssinia is portrayed as a complete political entity with the bordering and green shading (perhaps a bit of a fiction, considering the state of civil unrest) and regions are clearly recognizable. Tigre province, with the city of Axum, appears in the north, Gonder is in the proximity of Lake Tana, Shoa province is to the south in the highlands, and numerous other provinces are accurately depicted. The extent of Abyssinia is proportionately limited and the Red Sea is correct, with islands and Arab coastal cities designated. In contrast to Abyssinia, the hinterlands of the Ethiopian sub-system appear quite bleak and foreign; virtually nothing appears in what is the Ogaden to the southwest, until "Mogadasho" on the coast of the Indian Ocean.

By the end of the Zamana Masafent in 1855, Ethiopia was firmly involved in the incorporation process of the European world-system. It had long been linked to the Red Sea region through the transshipment of the caravan trade and as the location of port exchanges. Further, by mid-century diplomatic relations were becoming regularized and the tremendous influx of firearms would prove to be a mechanism both for further political consolidation and fragmentation (Caulk 1972). However divisive the import of firearms proved to be, they were central to the eventual rejection of European colonial aspirations. By the late nineteenth century the possession of firearms became a precondition for national leadership, and thousands of the most modern rifles were being shipped into Ethiopia. Ethiopian rulers easily played the British against the French - and vice versa - to supply weapons, and even "commissioned Greeks to buy muskets . . . and to smuggle then in through Turkish occupied territory" (Pankhurst 1965:27). Political favoritism and smuggling proved a successful strategy for weapons accumulation, and it was only when this dual strategy broke down that Italy successfully invaded in 1935 .

Thomas (1937:120) describes the region's transition: "The country was brought within the horizon of European politics by Bonaparte's persistent Oriental policy; and the sending of the first British diplomatic mission in 1805 to counteract this opened the way for a stream of European traders, missionaries, and travelers that has continued fairly steadily from that time on." This transition was solidified in the latter half of the century, as "with the reign of Menelik there began a network of surveys and exploration in every direction" (Thomas 1937:120). The next stage was one of finalizing internal political consolidation, which resulted in Ethiopia effectively entering the European world-system as an independent African polity. Thus, the first threequarters of the nineteenth century are the final transition of Ethiopia into the world-system.

\section{Incor poration and Resurrection of Empire (1855-1895)}

The transition and consolidation from the Zamana Masafent was by no means immediate. By 1855 one man again dominated Ethiopia: Lij Kassa Haylu, who was crowned the head of the church and took the throne name Tewedros (r. 1855-1868). Tewedros aspired to reestablish a cohesive Ethiopian state, and sought to reform the church and administration. He established a standing army, salaried governors and judges, confiscated some church lands and attempted to tax what he viewed as a corrupt and divisive church. He turned to the West, particularly Britain, for technical assistance, craftsmen and teachers, and sought an Anglo-Ethiopian alliance against encroaching Muslim power. When relations broke down in 1868, Tewedros took British hostages, which prompted invasion and eventually defeat by a British expeditionary force, after which he committed suicide (Marcus 1994:63-72; Stevens 1981:19-21). 
That Ethiopia did not fall back into Gonderine chaos speaks favorably to the seeds of national unity that Tewedros planted. Only three main contenders for national control emerged. The first, Dejazmatch ${ }^{16}$ Kassa Mercha of Tigray was governor of the northern province and had been in rebellion against the crown since 1865-66, outraged by Tewdros's efforts to tax the church and appropriate church holdings. Having assisted the British expeditionary force with wheat and barley and by securing supply lines to the coast, Dej. Kassa was rewarded with "military aid worth approximately $£ 500,000$, including artillery, muskets, rifles and munitions" (Marcus 1994:72). The second imperial contender, Wagshum Gobeze, was Kassa's brother-inlaw. Holding control over the central highlands, Gobeze was crowned Emperor Tekle Georgis II in 1868, but held a tenuous position in the interior. Cut off from a ready supply of arms, Tekle Georgis was defeated by the smaller, better-equipped Tigray army when he attempted to bring Kassa Mercha under his control. Kassa Mercha was crowned "king of kings" in Aksum in 1872, and took the throne name Yohannes IV (r. 1872-1889) (Marcus 1994:72; Stevens 1981:20-21).

The third contender for the throne was Menelik II of Shewa. King of Shewa, Menelik traced his lineage back to the Solomonic line and held power in the southern part of the empire. As Yohannes was distracted with issues of consolidation in the north, Menelik spread his rule to the south and west, eventually strengthening his position with the acquisition of European firearms. Italy was the primary source of these weapons, as Italy hoped to use Menelik against Yohannes, who had closer relations with the British and had gained considerable war materiel after defeating well-equipped Egyptian forces in 1875 and 1876. Pankhurst (1965:29) documents that "the Emperor captured something like 20,000 Remingtons, the most modern rifles of the day, a considerable amount of artillery, including 25 to 30 cannon, as well as many horses, mules, camels and food supplies. Understandably enough the Emperor refused all Egyptian demands for the return of his booty." After the striking victory, in the south many Shewans were reluctant to confront an emperor who had defeated the despised Muslims, especially one that was now wellequipped with the most modern arms. After hard negotiations Menelik II formally submitted to Yohannes, in return for the Emperor's promise to respect Shewa's sovereignty as long as the province remained faithful (Marcus 1994:73-76, Stevens 1981:20). By this act of submission, Yohannes then became the first emperor in centuries to consolidate and wield authority from Tigray in the north, south to Gurage.

European powers continued to try and exploit the political division between Menelik and Yohannes, and thereby reinforce the relative freedom that made Shewa the source of Ethiopian expansionism. Why was Shewa expansionist? In order to meet the biannual tribute given to Yohannes, Menelik looked to the south for conquest, where people had only traditional weapons. Menelik needed firearms to consolidate power and promote expansion. Italy hoped to gain his favor by providing them: "total supplies from Italy in 1888 were reported to have comprised 4,000 Remington rifles with 200,000 cartridges, 5,000 other rifles and 400,000 Weterley cartridges. Shortly afterwards, on January 28, 1889, Antonelli brought Menelik a further welcome gift of 5,000 rifles, and 1,000,000 Weterley cartridges" (Pankhurst 1965:30).

Menelik assumed the imperial throne after Yohannes was killed in 1889 fighting the Sudanese, well-supplied to defend the Empire against Italian aggression. In fact, though territory continued to be ceded, Ethiopia survived intact under Menelik into the 1930s. He established a

16 "Dejazmatch" (abbr. "Dej.") translates literally as 'commander of the gate' and denotes a title of nobility equivalent to a count. 
permanent capital at Addis Ababa in 1893 which developed into a true urban center (Pankhurst 1961). Menelik more than doubled the size of Ethiopia through conquest to the south, though European colonial powers continued to show interest in northern territory along the Red Sea coast. Complete recognition of Ethiopia as a power sovereign from Europe came in 1895, when Menelik's army defeated Italian forces that had invaded the northern province of Tigray (Stevens 1981:23-24; Marcus 1994:91-103).

\section{INCORPORATION, CONTEST PERIPHERIES AND 'PROTOGLOBALIZATION': SUGGESTIONS AND CONCLUSIONS}

At the beginning of the Scramble for Africa in $1885,{ }^{17}$ Ethiopia was already part of the international community and a functioning element in the world-system. But this did not mean that it was immune to the territorial predations of European nations. Rather, it merely meant that it had a better position from which to withstand them. Much in the same manner that the Ottoman Empire would be carved up, Ethiopia found itself being eaten away along the edges of its territory. This is likely to be evidence of being a contest periphery: gradual and incremental territory loss. Historically stretching to the Red Sea coast, Ethiopia was effectively landlocked by the turn of the twentieth century. For an empire whose socio-political history was based on its ability to exploit trade to and from the Red Sea ports, this was especially troubling. It was precisely because Ethiopia was effectively cut off from outside arms supplies in 1935, when Britain and France were cowed into refusing Ethiopia transport of arms across their colonial frontiers, that Mussolini was finally able to invade Ethiopia and realize the long-held Italian colonial aspirations. Improved firearms available to Italy but not Ethiopia, as well as the advent of new weapons of warfare such as the tank, the airplane, and poison gas made the outcome rather predictable (Pankhurst 1965:20).

So what type of preliminary conclusions can we come to regarding the sequencing of Abyssinian incorporation? To begin to answer this, let us turn to a modified typography of incorporation for Abyssinia.

In many ways the case of Abyssinia becoming incorporated is much more complex than other cases of basic incorporation (cf., Hollis 2005, Carlson 2002). Abyssinia is less isolated, not as "pristine", and more closely tied to historic trading systems and 'global' forces. As such, this is an added challenge when dealing with contest peripheries - the layers of interaction are longer and more overwritten. Thus, the image of a palimpsest is fitting: the region was continuously being renegotiated, pulsating in and out of contending systems, and gaining and losing territory. Abyssinia's relationship with the Red Sea trade - and by extension the larger network of the Indian Ocean - is a defining characteristic. The health of the governing polity, from the time of Axum to Menelik II, was directly tied to an ability to exploit these systemic interactions. In this sense, Ethiopian incorporation is best conceived as contextually dependent on the Red Sea trade: the Red Sea trading network is the grooming process for incorporation. This is evident in the rise of the Golden Age of the Solomonic Dynasty up to 1500 , not to mention the preceding rise and

\footnotetext{
${ }^{17}$ As Pankhurst (1965:30) reminds us, the Scramble - as far as this part of the continent was concerned "may be said to have begun on February 5, 1885, when the Italians occupied the port of Massawa. Five years later the Italian colony of Eritrea was proclaimed in what had hitherto been Northern Ethiopia."
} 
fall of Axum. Only when the Indian Ocean-Red Sea complex is disrupted with the arrival of the Portuguese and their subsequent blocking of the Red Sea does the region go into decline. This is not coincidental. Once trade begins to be stimulated again with the encroachment of European powers and Muslim activity out of Egypt, political transformation begins to occur. By the turn of the nineteenth century, the region is well known to Europe, though consolidation and expansion continues through mid-century, with the Zamana Masafent coming to an end by 1855 . With unification in 1877, Ethiopia was effectively incorporated and beginning to be peripheralized. Thus, much of the conflict that ultimately results in Italy's defeat in 1895 is actually peripheral competition and jockeying for favorable position within the European system.

Figure 7: Abyssinian Incorporation. Typography of Abyssinian Incorporation, adapted from Carlson (1999:30, 2001:249, 2002:431).

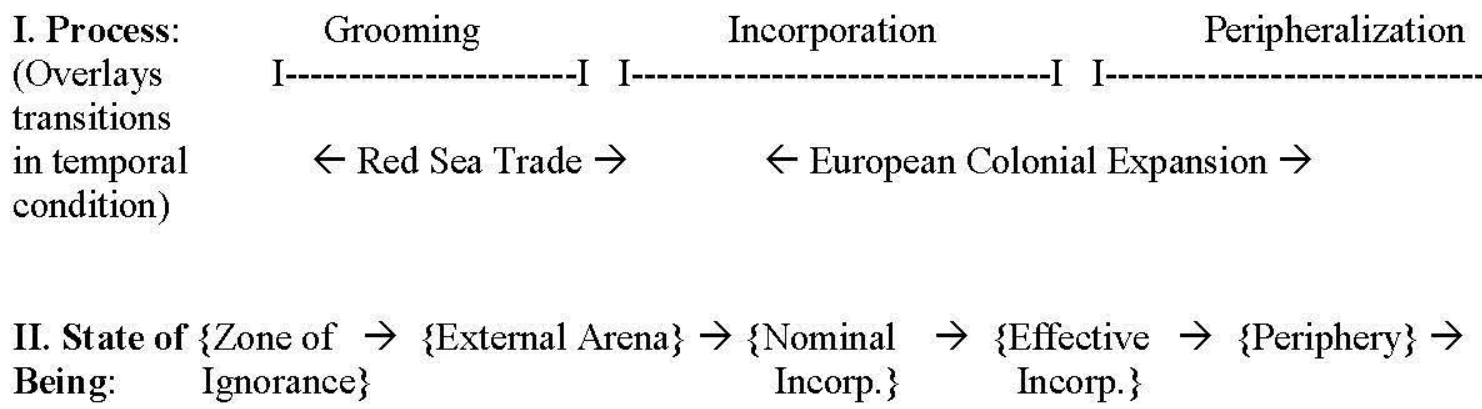

III. Signaling 1. Solomonic Dynasty

Events (to 1500) $\rightarrow$

2. Decline (to 1769)

$\leftarrow \quad$ \{Unification 1877 \}

3. Tranformation/Zamana Masafent \{Italy defeat

$\rightarrow$ (to 1855$)$

It is also difficult to precisely determine when Abyssinia passes through a particular state of being or transitions into a given network of interaction. However, this is to be expected. Why? Because we are examining an established trading system and a developed polity. The very antiquity of the region and the interaction of the primary actors mean that we are concerned with the integration of systems, not just an individual polity. Accordingly, the transition between states of being - and the transition from various networks of interaction (ZI, IN, PGN, PMN, $\mathrm{BGN}$ ) are all likely to be temporally compressed. Because these networks are already nested in an "exterior" system, once a trade-based relationship begins the other 'membranes' of that system are quickly breached. The 'natural' evolution of trade and information exchanges is effectively jump-started. This is one area - the interaction of systems on one another - that is seriously under-theorized in most world-systems literature. 
Breaking apart the information network is a good way to get at the inter-systemic dynamics that occur, especially with the zone of ignorance. If one limits a world-systems analysis to the temporal bounds as described by Wallerstein, Abyssinia has always existed on the fringes of the information network of the world system. The first reports of the mythic kingdom of Prester John in the twelfth century predate the emergence of even a germinal capitalist worldsystem, and it still exerted a tremendous pull on the European imagination. Finding the Christian King was an added incentive pushing Portugal around Africa. By the time Europe expanded into the Indian Ocean, Abyssinia was shifting solidly into the information network. Moreover, the supply of Portuguese musketeers, and the subsequent influx of priests and other interested parties, should be considered part of the incorporative process.

Regardless, by the $1500 \mathrm{~s}$ the regions were becoming increasingly intertwined. Yet because we are looking at an established polity, Abyssinia was able to expel the Jesuits and Roman Catholics because of perceived negative impacts associated with "incorporation". A less developed polity would not have been able to resist - or negotiate externality - in such a manner. On one hand this reflects the political development of the modern Ethiopian state. The period of political transformation known as the Zamana Masafent begins precisely because the region is linked to the outside system, and parallels the political reorganization - or the "creative destruction' - envisioned by Wallerstein as a necessary precursor to incorporation.

In this case, however, the external region is able to manage its own political structures instead of having them inserted by European powers. While the incorporation process begins with the political transformations of the age of princes, it is not complete until the ascendance of Yohannes. In turn, this is reflected in the cartographic treatment of Ethiopia. By 1806, it is one of the few regions in Africa that are known enough to be part of the 'outside world', precisely because it was also politically developed. This level of political development allowed Ethiopia to administratively 'out compete' the European colonial powers in a local context throughout the $1800 \mathrm{~s}$. While firearms were crucial to maintaining physical independence, the means by which they were acquired speaks to the capacity of the Ethiopian state. As long as Menelik could play one colonial interest against another, the benefit accrued to Ethiopia and the 'Lion of Judah' prevailed. When the flow of arms was finally cut off by an assertive Mussolini, then Ethiopia was isolated from the international community - and the world stood by and let it fall to Italian aggression. Yet this only reaffirms the longstanding, and symbiotic, role Abyssinia had with 'external' actors.

How far back can the impacts of protoglobalization be traced? In the case of Abyssinia the linkages arguably go all the way back to the dawn of humankind and the migration of humans out of the African continent. In many ways, migration is a constant aspect of human reaction to adversity, so can be viewed as such and not just a contemporary challenge of globalization (Kardulias and Hall 2007). Dealing with slightly more recent history, there is ready analogue for cross-cultural religious conflict and cooperation. In particular, a key motivation behind European fascination with Ethiopia was because of the Prester John myth: the belief that there was an ally, but more importantly a Christian ally, on the other side of the Muslim wall that encircled Europe. Early concern with cross-border environmental issues is also present, as the snows of Ethiopia were believed (or not believed) to impact flooding on the Nile, thus prompting further exploration of the Nile basin. So quite easily, three of the most contentious problems of twenty-first century globalization (immigration/migration, religious conflict, and environmental concerns) can be 
traced hundreds of years - if not thousands of years - into the past. The roots of globalization run deep.

Similarly, ancient trade networks within the Indian Ocean-Red Sea-Mediterranean Sea complex echo modern financial and economic issues. Axum was minting a truly "international currency", in a Roman denomination, using Greek markings, for use throughout the Middle East and Mediterranean basin! It is also noteworthy that upon the arrival of the Portuguese in the Indian Ocean, Abyssinia immediately felt the negative impact of the closure of the Red Sea. This indicates that when we consider incorporation, trade diversion is also a reliable indicator of 'impact' and may mark the onset of the 'grooming' process of an encroaching system. This is the dynamic nature of a 'contested periphery'.

Other aspects of protoglobalization are evident in the dispersal of agriculture, notably coffee, and agriculture is also a motivation for modern Ethiopian activity in the international community; Ethiopia was a signatory member of the International Institute of Agriculture in 1908 , one of the first major international organizations. And it is with recognized irony that the one of the keys to Ethiopia being recognized as a full member of the international community lay in its ability to get modern arms from the outside world. This independent sovereign status allowed Ethiopia the opportunity to become an active and accepted member of international society, as indicated by decades of official treaties, diplomatic recognition, and membership in multinational bodies, but especially the League of Nations by 1923 . Only when access to the most modern weapons was cut off did Ethiopia fall, sacrificed on the altar of the international community' that it helped create.

What we can take from the preceding case study is fourfold. First, it serves as an additional case of incorporation that scholars can use to refine or rebut elements of the worldsystemic understanding of incorporation. In particular, the existence of an information network is readily present and visible by using historic maps. But beyond this, and captured within the maps themselves is an underappreciated aspect of systemic expansion: the important role of myth and fantasy. Not knowing and merely believing is often more important for the expansion into new regions than having accurate information. Accordingly, the "zone of ignorance" at the edge and beyond the information network helps capture the fuzziness that characterizes early stages of incorporation. Arguably, this concept could also be expanded to contemporary notions of "emerging markets", resource exploration, seabed mapping, expenditures on technological innovation, or other areas of modern systemic expansion that are other than purely cartographic or historic, as the zone of ignorance is not purely a cartographic nor outdated phenomenon. Wishful thinking leads to the most remarkable undertakings.

Second, the concept of "contest peripheries" needs further development and additional research on cross-systemic incorporation should be done. As much research on incorporation focuses on 'clean' cases that can be easily studied in and of themselves (cf., Carlson 2001:251252), the bulk of systemic expansion is likely to be of polities other than those of a small or isolated nature. Simply, now that a model of incorporation along the lines of Chase-Dunn and Hall's (1991, 1997) and Hall's (1986, 1989, 1999a, 1999b, 2009) notion of nested networks of interaction has been developed, tougher cases of incorporation that include contest peripheries needs to be undertaken ( $c f$. ., Allen 1992, 1997, 2005; Cline 2000; Hall 2005). Since this case study lends support to the "pulsation thesis" of world-systems (Hall 1987, 1989, 2005; ChaseDunn and Hall 1997; Beaujard and Fee 2005), this is likely to be a considerable and complex task. Put simply, repeated experiences of "incorporation" are likely to have occurred for many 
regions of the world, particularly those on the borders of rival civilizations or cultures. Multiple palimpsests exist, and reading the scriptio inferior is time-consuming and prone to differing interpretations.

The notion of repeated incorporation transitions to a third, and related fourth, point worth reiterating. Third, this case further solidifies the application of world-system analysis to precapitalist settings, as has been argued by Abu-Lughod (1989, 1993), Chase Dunn and Hall (1991), Frank (1990, 1998), Frank and Gills (2005), Gills and Frank (1991). Of particular interest, was the systemic linkage and purposeful development of a "proto-global" currency by Axum. As such, a careful reading of Abyssinian history echoes "modern" concerns with globalization and argues that instead of being truly new or novel, the many problems subsumed under the rubric of globalization have a considerable historical legacy ( $c f$., Gills and Thompson 2006). In reference to this lengthy historical legacy, I offer the notion of "protoglobalization" as a means of differentiating the roots or precursor homologues of the "modern" phenomena. The rapidity of change is new - yet the challenges themselves are not. Accordingly, the interaction between systems is also useful for contemporary discussions about cultural globalization and civilizational 'clashes'. The process - or interrelated processes - of globalization have been taking place for thousands of years. Studying earlier cases of systemic incorporation, contest peripheries, and changes along the various networks of systemic interaction can provide us with a better understanding of how to negotiate these "modern" challenges.

\section{ACKNOWLEDGEMENTS}

This paper benefited from access and resources made available through the Helen Wallis Fellowship of The Map Library at The British Library, and through graduate and travel support provided by the Political Science Department at Arizona State University. The author also thanks the anonymous reviewers at JWSR for their helpful comments. With regard to errors or omissions, the usual statement applies.

\section{REFERENCES}

Abu-Lughod, Janet L. 1989. Before European Hegemony: The World System A.D. 1250 - 1350. New York: Oxford University Press.

. 1993. "Discontinuities and Persistence: One World System or a Succession of World Systems?" in Andre Gunder Frank and Barry K. Gills, eds. The World System: Five Hundred Years or Five Thousand? London, UK: Routledge, pp. 278-290.

Allen, Mitchell. 1992. "The Mechanisms of Underdevelopment: An Ancient Mesopotamian Example." Review 15: 3 (Summer) pp. 453-476.

. 1997. "Contested Peripheries: Philistia in the Neo-Assyrian World-System." Unpublished $\mathrm{Ph} . \mathrm{D}$. dissertation, Interdepartmental archaeology program, UCLA.

. 2005. "Power is in the Details: Administrative Technology and the Growth of Ancient Near Eastern Cores." Pp. 75-91 in The Historical Evolution of World-Systems, edited by Christopher Chase-Dunn and E. N. Anderson. New York: Palgrave. 
Aregay, Merid W. 1988. "The Early History of Ethiopia's Coffee Trade and the Rise of Shawa", The Journal of African History, vol. 29:1, pp. 19-25.

Arrowsmith, Aaron. 1808. "Map of the World on a Globular Projection", first published 1794. London, UK: A. Arrowsmith. Electronic image courtesy David Rumsey Historical Map Collection, copyright Cartography Associates: http://www.davidrumsey.com/maps924.html

Bagrow, Leo. 1966. History of Cartography, revised and enlarged by R. A. Skelton. Cambridge, MA: Harvard University Press.

Beaujard, Philippe. 2007. 'L'Afrique de 1'Est, les Comores et Madagascar dans le SystèmeMonde Eurasiatique et Africain avant le 16e Siècle" L'Afrique et Madagascar, pp. 29102, D. Nativel and F. Rajaonah (eds), Paris: Karthala.

Beaujard, Philippe and S. Fee. 2005. "The Indian Ocean in Eurasian and African World-Systems before the Sixteenth Century" Journal of World History (December) 16: 4, pp. 411- 465. http://www.historycooperative.org/journals/jwh/16.4/beaujard.html.

Bennyhoff, James A. and Richard E. Hughes. 1987. Shell Bead Ornament Exchange Networks between California and the Western Great Basin. New York: American Museum of Natural History.

Bull, Hedley. 1984. "The Emergence of a Universal International Society," in Hedley Bull and Adam Watson, eds. The Expansion of International Society. Oxford, UK: Clarendon Press, pp. 117-126.

Carlson, Jon D. 1999. "World-Systems Incorporation and the Zone of Ignorance: The Northwest Fur Trade," Paper presented at the annual meeting of the Western Political Science Association, March 25-27, Seattle, WA.

. 2001. "Broadening and Deepening: Systemic Expansion, Incorporation and the Zone of Ignorance", Journal of World-Systems Research, 7: 2 (Fall), pp. 225-263, http://jwsr.ucr.edu/volumes/vol7/Carlson-v7n2.pdf .

. 2002. "The 'Otter-Man' Empires: The Pacific Fur Trade, Incorporation and the Zone of Ignorance", Journal of World-Systems Research, 8: 3 (Fall), pp. 390-442, http://jwsr.ucr.edu/volumes/vol8/Carlson-v8n3.pdf.

Caulk, R. A. 1972. "Firearms and Princely Power in Ethiopia in the Nineteenth Century", The Journal of African History, vol. 13:4, pp. 609-630.

Chase-Dunn, Christopher and Thomas D. Hall. 1997. Rise and Demise: Comparing WorldSystems. Boulder, CO: Westview Press.

Chase-Dunn, Christopher and Thomas D. Hall, eds. 1991. Core/Periphery Relations in Precapitalist Worlds. Boulder, CO: Westview Press.

Cline, Eric H. 2000. '"Contested Peripheries' in World Systems Theory: Megiddo and Jezreel Valley as a Test Case" Journal of World-Systems Research (6:1) pp. 7-16, http://jwsr.ucr.edu/archive/vol6/number1/v6n1_pdf/jwsr-v6n1-cline.pdf.

"Convention between the United States of America and Italy, Montenegro, Russia, Argentine Republic, Roumania, Servia, Belgium, Salvador, Portugal, The United Mexican States, Luxemburg, The Swiss Confederation, Persia, Japan, Ecuador, Bulgaria, Denmark, Spain, France, Sweden, The Netherlands, Greece, Uruguay, Germany, Cuba, AustriaHungary, Norway, Egypt, Great Britain, Guatemala, Ethiopia, Nicaragua, Brazil, Costa Rica, Chile, Peru, China, Paraguay, and Turkey, Providing for the Creation of an 
International Institute of Agriculture", American Journal of International Law, vol. 2:4 (October 1908), pp. 358-362.

Crummey, Donald. 1975. "Society and Ethnicity in the Politics of Christian Ethiopia during the Zamana Masafent", The International Journal of African Historical Studies, vol. 8:2, pp. 266-278.

1990. "Society, State and Nationality in the Recent Historiography of Ethiopia", The Journal of African History, vol. 31:1, pp. 103-119.

Crummey, Donald and Shumet Sishagne. 1991. "Land Tenure and the Social Accumulation of Wealth in Eighteenth-Century Ethiopia: Evidence from the Qwesqwam Land Register", The International Journal of African Historical Studies, vol. 24: 2, pp. 241-258.

Diamond, Jared. 1997. Guns, Germs, and Steel: The Fates of Human Societies. New York: W.W. Norton \& Company.

Ehret, Christopher. 1979. "On the Antiquity of Agriculture in Ethiopia", The Journal of African History, 20:2, pp. 161-177.

Frank, Andre Gunder. 1990. "A Theoretical Introduction to Five Thousand Years of World System History," Review 13:2 (Spring), pp. 155-250.

1998. ReOrient: Global Economy in the Asian Age. Berkeley, CA: University of California Press.

Gills, Barry K. and Andre Gunder Frank. 1991. "5000 Years of World System History: The Cumulation of Accumulation", in Chase-Dunn and Hall, eds., Core/Periphery Relations in Precapitalist Worlds. Boulder, CO: Westview Press.

Gills, Barry K. and William R. Thompson, eds. 2006. Globalization and Global History. New York: Routledge.

Hall, Thomas D. 1986. "Incorporation in the World-System: Toward a Critique," American Sociological Review, 51, 390-402.

. 1987. "Native Americans and Incorporation: Patterns and Problems," American Indian Culture and Research Journal, 11:2:1-30.

. 1989. Social Change in the Southwest, 1350-1880. Lawrence, KS: University Press of Kansas.

. 1999a. "Precapitalist World-Systems", in Encyclopedia of Political Economy, vol. 2, Phillip Anthony O’Hara, ed. New York: Routledge Publishing, pp. 897-900.

. 1999b. "World-System: Incorporation Into," in Encyclopedia of Political Economy, vol. 2, Phillip Anthony O’Hara, ed. New York: Routledge Publishing, pp. 1265-1267.

. 2005. "Mongols in World-Systems History" Social Evolution \& History (4:2) pp.89-118.

. 2009. "Puzzles in the Comparative Study of Frontiers: Problems, Some Solutions, and Methodological Implications" Journal of World-Systems Research, (15:1) pp. 25-47, http://jwsr.ucr.edu/archive/vol15/Hall-vol15n1.pdf.

Hollis, Shirley. 2005. "Contact, Incorporation and the North American Southeast," Journal of World Systems Research, 11:1, pp. 95-130, http://jwsr.ucr.edu/archive/vol11/number1/pdf/jwsr-v11n1-hollis.pdf.

Homem, Diogo. 1558. "Chart of the Indian Ocean" [Map], in Queen Mary's Atlas, The British Library, shelfmark MS 5415A, reproduced in Leo Bagrow (1966) History of Cartography, revised and enlarged by R. A. Skelton. Cambridge, MA: Harvard University Press, pp. 144-145 (inset).

Hondius, Jodocus. 1613. "Abissinorum sive Pretiofi Ioannis Imperiu" [map], Amsterdam. 
Horvath, Ronald J. 1969. "The Wandering Capitals of Ethiopia", The Journal of African History, vol. 10:2, pp. 205-219.

Huntington, Samuel P. 1993. "The Clash of Civilizations?" Foreign Affairs, 72:3 (Summer) pp. 22-49.

Jesman, Czeslaw. 1963. The Ethiopian Paradox. New York: Oxford University Press.

Kardulias, P. Nick. 1999. "Multiple Levels in the Aegean Bronze Age World-System," in P. Nick Kardulias, ed. (1999). World-Systems Theory in Practice: Leadership, Production and Exchange. Lanham, MD: Rowman \& Littlefield Publishers, Inc., pp.179-201.

. 2007. "Negotiation and Incorporation on the Margins of World-Systems: Examples from Cyprus and North America", Journal of World-Systems Research, 13: 1, pp. 55-82, http://jwsr.ucr.edu/archive/vol13/Kardulias-vol13n1.pdf.

Kardulias, P. Nick, and Thomas D. Hall. 2007. "A World-Systems View of Human Migration Past and Present: Providing a General Model for Understanding the Movement of People" Forum on Public Policy. http://www.forumonpublicpolicy.com/archivesum07/kardulias.pdf.

Karklins, Karlis. 1980. A Bibliography of Glass Trade Beads in North America. Moscow, ID: South Fork Press.

Lewis, Bernard. 1990. Race and Slavery in the Middle East. New York: Oxford University Press.

Marcus, Harold G. 1971. "The Black Men Who Turned White", Archiv Orientali, 39, pp. 155166. 1994. A History of Ethiopia. Berkeley, CA: University of California Press.

Mazrui, Ali. 1984. "The Semitic Impact on Black Africa: Arab and Jewish Cultural Influences", Issue, 13, pp. 3-8.

Mercator, Gerard. 1569. "Nova et Aucta Orbis Terrae Descriptio..." [map], Duisburg, in Peter Whitfield (1994) The Image of the World. London, UK: The British Library, pp. 66-67.

Munro-Hay, Stuart. 1991. Aksum: An African Civilisation of Late Antiquity. Edinburgh, UK: Edinburgh University Press.

Nowell, Charles E. 1953. "The Historical Prester John", Speculum, 3 (July), pp. 435-445.

Ortelius, Abraham. 1573. "Presbiteri Iohannis..." [map], in Theatrum Orbis Terrarum, Antwerp. Image from Peter Whitfield (1998) New Found Lands. London, UK: The British Library, pp. 165. Shelfmark Maps C.23.e. 12

Pankhurst, Richard. 1961. "Menelik and the Foundation of Addis Ababa", The Journal of African History, vol. 2:1, pp. 103-117.

. 1965. "Guns in Ethiopia", Transition, 20, pp. 26-33.

- 1997. The Ethiopian Borderlands: Essays in Regional History from Ancient Times to The End of the $18^{\text {th }}$ Century. Lawrenceville, NJ: The Red Sea Press.

Phillipson, David W. 2005. African Archaeology, $3^{\text {rd }} E d$. New York: Cambridge University Press.

Rand McNally and Company. 1904. "Abyssinia and Surrounding Countries" [map], Atlas of the World. Chicago, IL: Rand McNally, pp. 151.

Simoons, Frederick J. 1960. "Snow in Ethiopia: A Review of the Evidence", Geographical Review, vol. 50:3 (July), pp. 402-411.

Stevens, Richard P. 1981. "Historical Setting", in Harold Nelson and Irving Kaplan, eds., Ethiopia, a Country Study. Washington, DC: Foreign Area Studies, pp. 1-56. 
Tamrat, Taddesse. 1972. Church and State in Ethiopia: 1270-1527. New York: Oxford University Press.

Thomas, T. H. 1937. "Modern Abyssinia: A Selected Geographical Biography", Geographical Review, vol. 27:1 (January), pp.120-128.

Tibebu, Teshale. 1996. 'Ethiopia: The 'Anomaly' and 'Paradox' of Africa", Journal of Black Studies, vol. 26:4 (March), pp. 414-430.

"Treaty of Commerce between the United States and Ethiopia." 1914. American Journal of International Law, vol. 16:1 (January 1922), pp. 9-10.

Wainwright, G. A. 1942. "Early Records of Iron in Abyssinia", Man, vol. 42 (July-August), pp. 84-88.

Wallerstein, Immanuel. 1974. The Modern World-System I: Capitalist Agriculture and the Origins of the European World-Economy in the Sixteenth Century. San Diego, CA: Academic Press.

1980. The Modern World System II: Mercantilism and the Consolidation of the European World Economy, 1600-1750. San Diego, CA: Academic Press.

- 1989. The Modern World System III: The Second Era of Great Expansion of the Capitalist World-Economy, 1730-1840s. San Diego, CA: Academic Press.

Whitfield, Peter. 1998. New Found Lands: Maps in the History of Exploration. London, UK: The British Library. 